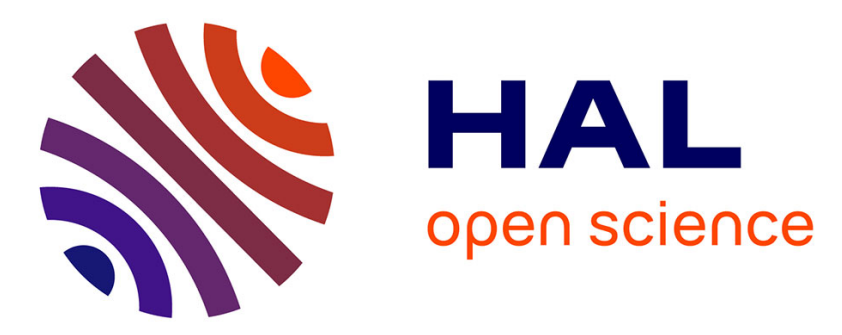

\title{
Sulfates and Iron Oxides in Ophir Chasma, Mars, based on OMEGA and CRISM observations
}

Lorenz Wendt, Christoph Gross, Thomas Kneissl, Mariam Sowe, Jean-Philippe Combe, Laetitia Ledeit, Patrick C. Mcguire, Gerhard Neukum

\section{- To cite this version:}

Lorenz Wendt, Christoph Gross, Thomas Kneissl, Mariam Sowe, Jean-Philippe Combe, et al.. Sulfates and Iron Oxides in Ophir Chasma, Mars, based on OMEGA and CRISM observations. Icarus, 2011, 10.1016/j.icarus.2011.02.013 . hal-00743842

\section{HAL Id: hal-00743842 \\ https://hal.science/hal-00743842}

Submitted on 21 Oct 2012

HAL is a multi-disciplinary open access archive for the deposit and dissemination of scientific research documents, whether they are published or not. The documents may come from teaching and research institutions in France or abroad, or from public or private research centers.
L'archive ouverte pluridisciplinaire HAL, est destinée au dépôt et à la diffusion de documents scientifiques de niveau recherche, publiés ou non, émanant des établissements d'enseignement et de recherche français ou étrangers, des laboratoires publics ou privés. 


\section{Accepted Manuscript}

Sulfates and Iron Oxides in Ophir Chasma, Mars, based on OMEGA and CRISM observations

Lorenz Wendt, Christoph Gross, Thomas Kneissl, Mariam Sowe, Jean-Philippe Combe, Laetitia LeDeit, Patrick C. McGuire, Gerhard Neukum

PII:

S0019-1035(11)00071-6

DOI:

10.1016/j.icarus.2011.02.013

Reference:

YICAR 9730

To appear in:

Icarus

Received Date:

22 July 2010

Revised Date:

17 December 2010

Accepted Date:

15 February 2011

Please cite this article as: Wendt, L., Gross, C., Kneissl, T., Sowe, M., Combe, J-P., LeDeit, L., McGuire, P.C., Neukum, G., Sulfates and Iron Oxides in Ophir Chasma, Mars, based on OMEGA and CRISM observations, Icarus (2011), doi: 10.1016/j.icarus.2011.02.013

This is a PDF file of an unedited manuscript that has been accepted for publication. As a service to our customers we are providing this early version of the manuscript. The manuscript will undergo copyediting, typesetting, and review of the resulting proof before it is published in its final form. Please note that during the production process errors may be discovered which could affect the content, and all legal disclaimers that apply to the journal pertain. 
1 Sulfates and Iron Oxides in Ophir Chasma, Mars, based on OMEGA and CRISM

2 observations

4 Lorenz Wendt $^{\mathrm{a} 1}$, Christoph Gross ${ }^{\mathrm{a} 2}$, Thomas Kneissl ${ }^{\mathrm{a} 3}$, Mariam Sowe ${ }^{\mathrm{a} 4}$, Jean-Philippe

5 Combe $^{\mathrm{b} 5}$, Laetitia LeDeit ${ }^{\mathrm{c} 6}$, Patrick C. McGuire ${ }^{\mathrm{a} 7}$, Gerhard Neukum ${ }^{\mathrm{a} 8}$

6

$7 \quad{ }^{a}$ Institute of Geological Sciences, Freie Universität Berlin, Malteser Strasse 74-100,

812249 Berlin, Germany

$9 \quad{ }^{b}$ Bear Fight Institute, P.O. Box 667, Winthrop WA 98862, USA

$10{ }^{\mathrm{c}}$ German Aerospace Center (DLR), Institute of Planetary Research, Rutherfordstr. 2,

1112489 Berlin, Germany

12

13 11 lorenz.wendt@fu-berlin.de, Telephone: +493083870576, Fax:+493083870723

14 (corresponding author)

$15 \quad 2$ christoph.gross@fu-berlin.de

163 thomas.kneissl@fu-berlin.de

$17{ }^{4}$ mariam.sowe@fu-berlin.de

185 jean-philippe_combe@bearfightinstitute.com

19 6laetitia.ledeit@dlr.de

207 mcguire@geosci.uchicago.edu

218 gerhard.neukum@fu-berlin.de. 
22 We investigate the sulfate and iron oxide deposits in Ophir Chasma, Mars, based on

23 short-wave infrared data from the Compact Reconnaissance Imaging Spectrometer for

24 Mars CRISM and from the Observatoire pour la Minéralogie, l'Eau, les Glaces et

25 l'Activité OMEGA. Sulfates are detected mainly in two locations. In the valley between

26 Ophir Mensa and the southern wall of Ophir Chasma, kieserite is found both within the

27 slope of Ophir Mensa, and superposed on the basaltic wall of the chasm. Here, kieserite is

28 unconformably overlain by polyhydrated sulfate deposits and iron oxides. Locally,

29 jarosite and unidentified phases with absorptions at $2.21 \mu \mathrm{m}$ or $2.23 \mu \mathrm{m}$ are detected,

30 which could be mixtures of jarosite and amorphous silica or other poorly crystalline

31 phases.

32 The second large sulfate-rich outcrop is found on the floor of the central valley. Although

33 the same minerals are found here, polyhydrated sulfates, kieserite, iron oxides, and

34 locally a possibly jarosite-bearing phase, this deposit is very distinct. It is not layered,

35 almost horizontal, and located at a much lower elevation of below $-4250 \mathrm{~m}$. Kieserite

36 superposes polyhydrated sulfate-rich deposits, and iron oxides form lags.

37 The facies of sulfate formation remains unclear, and could be different for the two

38 locations. A formation in a lake, playa or under a glacier is consistent with the

39 mineralogy of the central valley and its flat, low-lying topography. This is not

40 conceivable for the kieserite deposits observed south of Ophir Mensa. These deposits are

41 observed over several thousands of meters of elevation, which would require a standing

42 body of water several thousands of meters deep. This would have lead to much more

43 pervasive sulfate deposits than observed. These deposits are therefore more consistent

44 with evaporation of groundwater infiltrating into previously sulfate-free light-toned 
45 deposits. The overlying polyhydrated sulfates and other mineral phases are observed in

46 outcrops on ridges along the slopes of the southern chasm wall, which are too exposed to

47 be reached by groundwater. Here, a water supply from the atmosphere by rain, snow, fog

48 or frost is more conceivable.

49

50 Keywords: Mars, Surface, Spectroscopy

51

52 [SUGGESTED RUNNING TITLE

53 Sulfates and Iron Oxides in Ophir Chasma, Mars 54 


\section{Introduction}

56 The Light-Toned Deposits [LTD] or Interior Layered Deposits [ILD] (Lucchitta et al., 1992)

57 within the chasmata of Valles Marineris are some of the most intensely studied geological

58 features on Mars. Many theories for their formation have been put forward, including subaerial

59 fluvial deposition or volcanism (Lucchitta et al., 1992), accumulation of eolian dust or sand

60 (Peterson, 1981), evaporite precipitation in lakes (McKay and Nedell, 1988) or from

61 groundwater (Murchie et al., 2009a), subaqueous (Nedell et al., 1987) or sub-ice volcanism

62 (Chapman and Tanaka, 2001), or the formation as spring deposits (Rossi et al., 2008), but a

63 conclusive theory combining all implications suggested by the composition, structure and

64 stratigraphic position of these deposits is still missing. A detailed discussion of the shortcomings

65 of each of the formation theories is provided by Lucchitta, 2009a; 2009b. One major constraint

66 on these theories is the role of liquid water, evidenced by the presence of ferric oxides and

67 sulfates, which are the subject of this study.

68 The mineralogy of the LTD's has been studied on a regional scale by Gendrin et al., 2005 and

69 Mangold et al., 2007, based on short-wave infrared (SWIR) data from the Observatoire pour la

70 Minéralogie, l'Eau, les Glaces et l'Activité OMEGA (Bibring et al., 2004), and by Weitz et al.,

712008 , based on thermal infrared data from the Thermal Emission Spectrometer TES (Christensen

72 et al., 1992). A comparative study on the geological context of the individual outcrops of

73 aqueous minerals in Valles Marineris by Chojnacki and Hynek, 2008, showed that the LTDs are

74 much more diverse than previously thought, which makes a single formation process explaining

75 all depositions by the same mechanism less likely, and which raises the need for individual,

76 detailed mineralogic and geologic studies for each of the basins of Valles Marineris. In this

77 paper, we analyze SWIR data from OMEGA and the Compact Reconnaissance Imaging 
78 Spectrometer for Mars CRISM (Murchie et al., 2007) in combination with multispectral

79 imagery, digital elevation models and stereo images from the High Resolution Stereo Camera

80 HRSC (Neukum and Jaumann, 2004), and panchromatic images from HRSC, the Context Imager

81 CTX (Malin et al., 2007) and the High Resolution Imaging Science Experiment HiRISE

82 (McEwen et al., 2007) acquired over Ophir Chasma in order to understand the mineralogy and

83 local stratigraphy and layering characteristics of the water-related minerals found here, mainly

84 sulfates and iron oxides. Similar studies on neighboring chasmata include the work of Mangold

85 et al., 2008, and Murchie et al., 2009a, on West Candor Chasma, Le Deit et al., 2008, on East

86 Candor Chasma, and Roach et al., 2010b, on Ius Chasma.

88 [INSERT FIGURE 1 HERE]

90 Ophir Chasma is the northernmost depression of central Valles Marineris. It extends

91 approximately $270 \mathrm{~km}$ in East-West direction and $90 \mathrm{~km}$ in North-South direction (Fig. 1). The

92 floor of the chasma lies at elevations between 4200 and $4800 \mathrm{~m}$ below datum, its rim is at

93 elevations between 3400 and $4500 \mathrm{~m}$ above datum. Most of the western part of Ophir Chasma is

94 covered by a mound of LTDs, Ophir Mensa, which rises up to an elevation of $3200 \mathrm{~m}$ above

95 datum. This results in a total thickness of (at least) $7-8 \mathrm{~km}$ of deposits, assuming that the floor

96 below Ophir Mensa is approximately horizontal at an elevation close to the deepest points of the

97 chasm. Ophir Mensa is surrounded on all sides by depressions, which separate these deposits

98 from the chasm walls. For convenience, we informally named the depression to the north as the

99 "northern moat", the depression to the south as "mineral bowl", following Chojnacki and Hynek, 
1002008 , and the depression to the east as the "central valley" (Fig. 1A). A second mound of light-

101 toned deposits is located between the central valley and the south-eastern rim of Ophir Chasma.

102 The geology of the LTDs was investigated by Nedell et al., 1987 and Komatsu et al., 1993, and a

103 geological map based on Viking imagery was provided by Lucchitta, 1999. According to these

104 authors, the chasmata of Valles Marineris probably formed as collapse structures along faults

105 that later widened to grabens into the surrounding Noachian to Hesperian aged plains, which are

106 built up by Tharsis-derived lava. By the time of the deposition of the LTDs, the chasm walls

107 were already eroded to the spur-and-gully morphology observable today, which indicates that the

108 deposition was clearly post-tectonic. Subsequently, the LTDs were heavily eroded by wind

109 and/or water action. The walls of the chasmata receded from the remaining LTD platforms, and

110 the resulting "moat" surrounding them was partly covered by landslides.

\section{Datasets and Methods}

\section{$112 \quad 2.1$ Hyperspectral data}

113 OMEGA and CRISM are both visible-short wave infrared imaging spectrometers. OMEGA

114 (Bibring et al., 2004) is the mapping infrared spectrometer onboard ESA's Mars Express

115 spacecraft. It covers the wavelength range from $0.38 \mu \mathrm{m}$ to $5.1 \mu \mathrm{m}$ in 352 contiguous bands. The

116 data is acquired by three different channels, one for the visible to near infrared spectrum $(0.38$ -

$1171.05 \mu \mathrm{m})$, a second for the spectral range from 0.93 to $2.73 \mu \mathrm{m}$ and a third covering the range

118 from 2.55 to $5.1 \mu \mathrm{m}$. We used mostly data from 0.93 to $2.73 \mu \mathrm{m}$, as this range covers electronic

119 transition absorptions due to olivine and pyroxene (Adams, 1974, Cloutis and Gaffey, 1991,

120 Sherman et al., 1982, Sunshine and Pieters, 1990), and vibrational absorptions in $\mathrm{H}_{2} \mathrm{O}$ and/or

121 hydroxyl-bearing minerals such as phyllosilicates, hydrated sulfates and oxyhydroxides (Burns, 
122 1993, Clark et al., 1990). The spectral resolution of OMEGA is $20 \mathrm{~nm}$ in this wavelength range.

123 Due to Mars Express' highly elliptical orbit, the spatial resolution of OMEGA varies between

$124300 \mathrm{~m}$ and 3-4 km per ground element. Most of the OMEGA data used in this study have a

125 spatial resolution in the order of 600 to $700 \mathrm{~m}$ per ground element.

126 CRISM (Murchie et al., 2007; 2009c) onboard NASA's Mars Reconnaissance Orbiter (MRO)

127 features a similar spectral range from 0.4 to $3.9 \mu \mathrm{m}$ in 544 bands at a spectral resolution of 6.55

$128 \mathrm{~nm}$, recorded by two distinct detectors, the "S"-detector in the range of 0.39 to $1.02 \mu \mathrm{m}$, and the

129 "L" detector in the range of 1.02 to $3.92 \mu \mathrm{m}$ wavelength. The data are acquired in several modes,

130 including the targeted mode at a spatial resolution of $18 \mathrm{~m}$ (FRT mode) or $36 \mathrm{~m} / \mathrm{pixel}$ (HRL

131 mode) using all bands, or in multispectral mapping (MSP) mode at a spatial resolution of $200 \mathrm{~m}$

132 per pixel using a subset of 72 selected spectral bands. We mostly used the data in the range of 1

133 to $2.6 \mu \mathrm{m}$, as this is the range where absorption bands of sulfates occur, but included the visible

134 range for the confirmation of the presence of ferric oxides. Table 1 provides the observation

135 numbers used here.

137 [INSERT TABLE 1 HERE]

139 The OMEGA and CRISM data were converted to I/F, divided by the cosine of the solar

140 incidence angle, and the $\mathrm{CO}_{2}$ absorption features around $2 \mu \mathrm{m}$ caused by the Martian atmosphere

141 were removed using the improved volcano-scan technique provided by McGuire et al., 2009.

142 Noise in CRISM data was reduced using various filtering procedures (Parente, 2008). We used

143 the spectral indices or "summary products" (Bishop et al., 2009; Murchie et al., 2009b; Pelkey et

$144 a l ., 2007)$ on OMEGA and CRISM data to identify spectral features characteristic for specific 
145 minerals or groups of minerals. Out of these, the index for a band at $1.9 \mu \mathrm{m}$ due to combinations

146 of $\mathrm{H}_{2} \mathrm{O}$ bending and stretching vibrations (BD1900), the $2.1 \mu \mathrm{m}$ band depth (BD2100) the band

147 depth at 2.21-2.26 $\mu \mathrm{m}$ due to Si-OH vibrations (BD2210) and the index quantifying the spectral

148 convexity around $2.3 \mu \mathrm{m}$ caused by $\mathrm{H}_{2} \mathrm{O}$ absorptions (SINDEX) were particularly useful to

149 identify regions that required detailed spectral analysis.

150 Ferric oxide was identified by its strong increase in reflection between 1 and $1.3 \mu \mathrm{m}$, which we

151 calculated as the ratio between the reflectance at $1.2767 \mu \mathrm{m}$ and the reflectance at $1.080 \mu \mathrm{m}$ for

152 CRISM data and the ratio between reflectance at $1.2705 \mu \mathrm{m}$ and $1.0837 \mu \mathrm{m}$ for OMEGA data,

153 similar to Le Deit et al., 2008; Mangold et al., 2008. This index is sensitive to ferric oxides or

154 oxyhydroxides like hematite and goethite or mixtures containing these minerals, but also to iron

155 bearing sulfates, like, for example, copiapite. We therefore corroborated the presence of ferric

156 oxides using the spectral data in the visible-near infrared range from the CRISM S detector. To

157 this end, we excluded the spectral data shortward of $0.41 \mu \mathrm{m}$ and longward of $0.97 \mu \mathrm{m}$ as well as

158 the range between 0.64 and $0.69 \mu \mathrm{m}$ due to known calibration problems in these regions of the

159 detector (Murchie et al., 2009c). Spectra of Mars in the visible wavelength range are dominated

160 by the presence of nanophase ferric oxides. The detection of coarse-grained red hematite,

161 goethite or other ferric phase therefore requires the calculation of spectral ratios to a reference

162 spectrum in the same observation, which is spectrally unconspicuous and dominated only by

163 dust. These reference spectra were calculated as average spectra over a few hundreds or

164 thousands of pixels. The spectral bands of ferric oxides, $\sim 0.53$ and $0.86 \mu \mathrm{m}$ for red hematite and

$165 \sim 0.5$ and $0.9 \mu \mathrm{m}$ for other ferric phases, were then made visible by removing the continuum

166 separately in the range of 0.41 to $0.64 \mu \mathrm{m}$ and 0.69 to $0.97 \mu \mathrm{m}$ (Clark et al., 1987). Further

167 evidence for the presence of ferric oxides in Ophir Chasma is the independent identification of 
168 grey hematite in the thermal infrared by TES (Weitz et al., 2008). Spectra in the range of 1 to 2.6

$169 \mu \mathrm{m}$ were averaged over regions of interest and either compared directly to laboratory spectra or

170 likewise ratioed to spectrally bland (dusty) regions. We used laboratory spectra of pure minerals

171 from the RELAB spectral library provided with the CRISM Analysis Tool (CAT).

172

173 An absorption band near $1.9 \mu \mathrm{m}$ is found in various types of minerals: Hydrated silica, hydrated

174 sulfates, phyllosilicates and also carbonates show this spectral feature, which makes further

175 absorptions necessary to distinguish between these groups of minerals. Monohydrated sulfates

176 show an absorption near $2.1 \mu \mathrm{m}$, which is detected by the BD2100 index. The exact location of

177 this absorption band is at $2.13 \mu \mathrm{m}$ for the magnesium-rich kieserite $\left(\mathrm{MgSO}_{4} * \mathrm{H}_{2} \mathrm{O}\right)$ and at 2.09

$178 \mu \mathrm{m}$ for the iron-rich szomolnokite $\left(\mathrm{FeSO}_{4} * \mathrm{H}_{2} \mathrm{O}\right)$. Both minerals also show an absorption at

$1792.4 \mu \mathrm{m}$ (Cloutis et al., 2006). A distinction between these two minerals was only attempted for

180 OMEGA and CRISM data at full spectral resolution. and not the multispectral data from CRISM,

181 as the generally higher noise level prevented an analysis to this detail.

182 Polyhydrated sulfates are identified by absorption bands at 1.45 and $1.95 \mu \mathrm{m}$ and a drop-off in

183 reflectance near $2.4 \mu \mathrm{m}$. Absorptions in the 2.2-2.3- $\mu \mathrm{m}$-region are indicative for hydrated silica,

184 phyllosilicates, or jarosite, and are attributed to $\mathrm{OH}$-stretching and $\mathrm{Si}-\mathrm{OH}$ bending. Hydrated

185 silica such as opal show a broad absorption band between 2.20 and $2.26 \mu \mathrm{m}$ due to overlapping

186 bands caused by hydroxyl-groups and water molecules in the hydrate sphere. Jarosite is

187 identified by absorptions at $1.47,1.85$ and a doublet at 2.21 and $2.26 \mu \mathrm{m}$. Phyllosilicates show a

188 narrow absorption band in the wavelength region between 2.2 and $2.31 \mu \mathrm{m}$. Its exact position

189 allows a distinction between aluminum-rich clays like montmorillonite $(2.20 \mu \mathrm{m})$, iron-rich

190 nontronite $(2.28 \mu \mathrm{m})$, and magnesium-rich saponite $(2.31 \mu \mathrm{m})$. 


\subsection{Panchromatic and multispectral imagery}

The High Resolution Stereo Camera HRSC (Neukum and Jaumann, 2004) combines nine CCD line detectors behind a common optics. The viewing directions of the detectors are oriented at angles between -18.9 and $+18.9^{\circ}$ with respect to the nadir view, and four of the sensors are equipped with broadband color filters for the red, green, blue and near infrared sections of the spectrum. This design allows for the simultaneous acquisition of panchromatic images with a map-projected ground resolution of up to $12.5 \mathrm{~m}$ per pixel, multispectral/color images and panchromatic multiple stereo ground coverage to produce digital terrain models (DTM). The resolutions of the color channels and the off-nadir panchromatic channels is usually reduced onboard by a factor of two or four with respect to the nadir channel to reduce the amount of data to be transferred to Earth (McCord et al., 2007).

The HRSC color images have been beneficial for the mapping of the dark, basaltic sand dunes and deposits (McCord et al., 2007; Williams et al., 2009), which have a bluish hue in colorstretched RGB representations of the red, green and blue HRSC channels, and for the distinction between Al- and Mg/Fe-rich clay minerals in Mawrth Vallis (Loizeau et al., 2007). Although a direct correlation between HRSC color spectra and specific minerals or rock types in other cases is difficult, the subtle color variations in HRSC images can and should be used to distinguish geologic units visually. We therefore used HRSC RGB representations of the red, green and blue HRSC channel, pansharpened with the higher resolved panchromatic, nadir-viewing HRSC channel or with CTX (Malin et al., 2007) images in several occasions in this study.

We investigated the geometry of the LTDs based on digital elevation models (DTM) with spatial resolutions of 50 or $100 \mathrm{~m}$ cell size, which were derived from individual HRSC orbits (Gwinner et al., 2000).We also used a regional DTM of the entire Valles Marineris at a resolution of $150 \mathrm{~m}$ cell size, which was produced from several bundle-block-adjusted HRSC orbits (Dumke et al., 
215 2010). We estimated the attitude of observed layers by fitting a plane through three or more

216 points selected in the HRSC DTMs along the outcrop of the layering observed in the co-

217 registered imagery (similar to Zegers et al., 2006) using the software tool developed by Kneissl

218 et al., 2010. In addition to this, anaglyphs were produced directly from the HRSC nadir channel

219 and one of the stereo channels, as these products provide more topographical detail than a DTM

220 produced from the same data.

221 We also used panchromatic imagery from the Context Imager CTX (Malin et al., 2007) with a

222 spatial resolution of approx. $6 \mathrm{~m}$ per pixel, and panchromatic and color images from the HiRISE

223 experiment (McEwen et al., 2007) with a spatial resolution of up to $25 \mathrm{~cm}$ per pixel.

\section{Results}

2253.1 Overview

226 Figure 1A shows Ophir Chasma as a false color mosaic of the red, green and blue channel of

227 HRSC. Figure 1B shows the mineral indices for iron oxides, sulfates (SINDEX) and

228 monohydrated sulfates (BD2100) calculated from OMEGA and CRISM data as a RGB image

229 overlain on a panchromatic HRSC mosaic. In this visualization, monohydrated sulfates appear in

230 a blue-green hue, polyhydrated sulfates have a green hue, and iron oxides are shown in red.

231 In the HRSC color image, dark, basaltic material appears with a bluish hue. It is found as a dune-

232 forming aeolian deposit in the central valley, the "mineral bowl", in wind traps along the

233 northern of Ophir Mensa and on top of the ILD east of the central valley. The basaltic sand

234 covers ILDs and landslides, its deposition therefore occurred after sulfate formation. The dark

235 material shows a spectral signature of pyroxenes and in the central valley of pyroxenes and

236 monohydrated (kieserite) deposits. Possible sources of the basaltic material are the eroding 
237 chasm walls and landslide material, and a possible late-stage volcanism (Lucchitta, 2002). In

238 nearby western Candor Chasma, dark, basaltic material shows a spectral signature of

239 monohydrated sulfates, and HiRISE images show distinct, friable layers within the ILDs, from

240 which the basaltic sands are released by erosion (Murchie et al., 2009a). Similar layers are not

241 found in Ophir Chasma. The ILDs appear to be mostly massive, without showing a layering

242 structure. Locally, dark bands are observed, e. g., east of the central valley. At close inspection,

243 these bands appear to be superficial, aeolian deposits on terraces caused by differential erosion

244 along layering in the ILDs, but not basalt-bearing layers within the ILDs. The fact that the

245 basaltic sand in the central valley shows spectral features of monohydrated sulfates does not

246 imply an origin of the basalts from within the ILDs, as suggested for western Candor Chasma, as

247 the sulfate signature is likely caused by the light toned kieserite deposits peeking through the

248 loose, dark sand cover. On the other hand, erosion of the chasm walls inevitably continued

249 during deposition of the ILDs independent of the depositional environment in the basin:

250 therefore, an incorporation of basaltic material into the ILDs most likely took place, but the lack

251 of distinct, dark layers suggests that this process played only a minor role. Consequently, the co-

252 occurrence of pyroxenes and sulfates does not imply a genetic relationship between the two

253 groups of minerals, which would allow a reconstruction of a common deposition.

254 Spectral signatures of iron oxides and sulfates are found only on a small fraction of the deposits

255 in Ophir Chasma, while most of the deposits are spectrally bland. Mangold et al., 2008,

256 Chojnacki and Hynek, 2008, and LeDeit, 2008, observed, that sulfates are found only in

257 consolidated rocks with an elevated thermal inertia in TES data, and concluded that sulfates

258 might be much more pervasive within the LTDs, but undetectable due to a cover of

259 unconsolidated dust. This general trend is correct, but many locations are spectrally bland despite 
260 relatively high thermal inertia values (Chojnacki et al., 2006). This is the case for the ILD

261 material on the northern flank of Ophir Mensa, which shows an elevated thermal inertia, but is

262 nevertheless spectrally featureless in CRISM and OMEGA data. Although optically thick dust

263 deposits could mask spectral features in the visible and near infrared region and at the same time

264 hardly affect the thermal radiation, these locations are on steep flanks with deep erosional rills

265 and free of dunes in high-resolution imagery, which does not suggest a dust cover.

267 The locations of sulfate and ferric oxide detections can be divided into three groups based on

268 their stratigraphy with respect to Ophir Mensa. The observations in the west of Ophir Mensa

269 (Fig. 2) and on the northern side of the "mineral bowl" suggest the presence of sulfates within the

270 deposits of Ophir Mensa. On the southern wall of the "mineral bowl" (and Ophir Chasma), the

271 stratigraphic relationship to Ophir Mensa is not completely clear. The outcrops in the "moat"

272 north of Ophir Mensa and in the central valley form the third group of deposits, as they appear to

273 overlay, and thus postdate the formation and erosion of the bulk of the light-toned deposits

274 making up Ophir Mensa. All outcrops will be discussed in detail in the following text.

275 Figure 1A also shows the location of a prominent marker horizon within Ophir Mensa as a

276 dashed, red line. This horizon shows several curves and can be traced from the western end of

277 Ophir Mensa up to its base at the eastern end of the "mineral bowl" valley. It mostly forms a

278 steep cliff approx. $500 \mathrm{~m}$ high (Fig. 2). Layer attitude measurements along this horizon indicate

279 that the layering generally dips outward, following the topography of Ophir Mensa (compare to

280 Zegers et al., 2006). In the west of Ophir Mensa, the horizon is located stratigraphically near the

281 top of the mound and dips approximately horizontally. In the center of Ophir Mensa, the horizon

282 appears to plunge at angles in the order of $5^{\circ}$ underneath the stratigraphically higher deposits of 
283 the eastern Ophir Mensa. Towards the flanks, dip angles increase to around $20^{\circ}$. A kink in the

284 slope is observed in the "mineral bowl", changing from $17^{\circ}$ directly above the marker horizon to

285 values around $10^{\circ}$ below it. Interestingly, the sulfate deposits within Ophir Mensa are only found 286 in the section beneath this horizon.

INSERT FIGURE 2 HERE

\subsection{Western Ophir Mensa}

292 Figure 3 shows a subset of the CRISM targeted observation FRT0000B27B in the western part

293 of Ophir Mensa. In this location, the LTDs show layering in the order of a few tens of meters in

294 thickness, which dip westward at moderate angles around $7^{\circ}$. Absorption bands near $1.6 \mu \mathrm{m}$,

$2952.1 \mu \mathrm{m}$ and at $2.4 \mu \mathrm{m}$ suggest the presence of monohydrated sulfates such as kieserite. The

296 slightly lower albedo and the presence of small dunes in the region showing a presence of

297 polyhydrated sulfates (green) in the HiRISE image PSP_008458_1760 (Fig. 3B) suggests that

298 the boundary of kieserite detection, which does not coincide with the layering, is caused by the

299 thin dust coverage, and not by a change of the mineralogy of the rocks in these layers. This

300 suggests that the ILDs of Ophir Mensa above the marker horizon are sulfate-free, whereas the

301 detection below this horizon is controlled by the presence or absence of a masking dust cover.

302 Thus, in the lower part sulfates might be much more abundant, despite only limited detections in 303 orbital data. 
305

306

307

308

309

310

311

312

313

314

315

316

317

\subsection{The "mineral bowl"}

[INSERT FIGURE 4 HERE]

The "mineral bowl" is the depression between Ophir Mensa and the southern wall of Ophir

Chasma. It extends approximately $70 \mathrm{~km}$ in East-West-direction and is up to $20 \mathrm{~km}$ wide (Fig.

4). It owns its informal name due to the complex relationship between spectrally bland ILDs of

Ophir Mensa and sulfates and crystalline ferric oxide detections within Ophir Mensa, on the southern wall, and on the valley floor (Chojnacki and Hynek, 2008). The southern wall itself is

built up from layers of basaltic rocks (Lucchitta, 1999). The spatial and spectral resolution of the

CRISM and OMEGA data of this valley is very diverse. Therefore, the mineralogy of this complex outcrop region can only locally be assessed in detail. We will provide an overview of the mineral phases observed, before discussing the relationship between Ophir Mensa and the southern chasm wall (Fig. 5) and between the southern chasm wall and the overlying LTDs (Fig. $6)$.

Starting in the eastern part of the northern slope of the valley, CRISM detects absorption bands at 1.6, 2.13 and $2.4 \mu \mathrm{m}$ consistent with kieserite at the base of Ophir Mensa and an erosional remnant of Ophir Mensa approx. one km towards the center of the valley. These outcrops show layering of tens of meters in thickness, and HiRISE imagery reveals even thinner internal layering in the meters scale. The layers were interpreted as the source of crystalline ferric oxides found in the dark material covering the floor of the valley (Weitz et al., 2008). The sulfate and hematite-bearing rocks form a bench, which is evidenced by a break in dip angles from approx. $17^{\circ}$ in the sulfate-free ILDs above to $10^{\circ}$ within the sulfate-bearing rocks. The floor of the "mineral bowl" drops towards the south and is covered by dark material, which appears to be a 
329 mixture of basaltic, pyroxene rich sand and crystalline ferric oxides, as evidenced by TES (Weitz

330 et al., 2008) and CRISM data. Several light-toned patches with a spectral signature of

331 monohydrated sulfates are found underneath this blanket. This suggests that the bench of sulfate-

332 rich material extends further south underneath the dark cover to the opposite slope of the valley.

333 In the center of the northern slope of the "mineral bowl", the sulfate-bearing bench forms a cliff

334 about 400 meters high. Polyhydrated sulfate deposits are observed near the top of the cliff,

335 monohydrated sulfate-rich deposits are found at the base and on the valley floor below. In the

336 western part of the "mineral bowl", the base of Ophir Mensa is heavily eroded and forms a deep

337 embayment towards the north, bound by steep flanks. OMEGA and CRISM data show kieserite

338 spectra on these walls up to an elevation of approximately $+250 \mathrm{~m}$. The observation of kieserite

339 spectra despite the heavy erosion suggests that fresh sulfates from within Ophir Mensa are

340 exposed, rather than being a thin surface coating on the Ophir Mensa slopes. On the valley floor,

341 layering of smooth, dark-toned, basaltic material and lighter-toned material with intermixed

342 sulfates and iron oxides can be observed. Locally, light-toned, sulfate-rich dunes are found.

344 [INSERT FIGURE 5 HERE]

346 The relationship between Ophir Mensa and the southern chasm wall is shown in Fig. 5.

347 Monohydrated sulfates are observed within the eroded base of Ophir Mensa and overlying the

348 spur-and-gully morphology of the southern chasm wall ("MHS in situ" in Fig. 5A), where they

349 are found from the foot of the slope at an elevation of $\sim-2200 \mathrm{~m}$ up to $\sim+800 \mathrm{~m}$. The thickness of

350 the light-toned cover of the southern wall appears to increase from the top to the bottom of the

351 southern slope, suggesting downslope movement of material. Several light-toned ridges are 
352 observed (white arrows in Fig. 5) covering the kieserite deposits, which have been described as

353 "pasted on" the underlying basaltic basement (Chojnacki and Hynek, 2008; Weitz et al., 2008)

354 based on MOC imagery (Malin et al., 1992). They are too small to be resolved in the CRISM

355 MSP data available here, but are very similar in texture to light-toned ridges further to the east,

356 (Fig. 6 and 7), showing a distinct mineralogy (see below). The kieserite on the southern slope of

357 the "mineral bowl" is overlain by rough-textured polyhydrated sulfates and locally ferric oxides.

358 The sulfate deposits on the southern wall end abruptly along an east-west-trending lineament we

359 interpret as a normal fault. Together with a parallel feature approx. two to three km northward it

360 forms a graben in the floor of the "mineral bowl" (center of Fig. 5A). The graben can be traced

361 further eastward as a depression with angular boundaries (top of Fig. 5B). The graben is filled

362 with smooth layers of monohydrated sulfates eroded from Ophir Mensa and the southern chasm

363 wall ("MHS, redeposited" in Fig. 5A). Partly, these monohydrated sulfate outcrops are covered

364 by spectrally bland material from further up the slope of Ophir Mensa.

365 The black arrows in Fig. 5 mark a "tongue shaped" deposit that bridges the gap between the

366 southern slope of Ophir Chasma and Ophir Mensa. It starts below the top of Ophir Mensa at

367 approx. $0 \mathrm{~m}$ elevation, stretches down the slope of Ophir Mensa to an elevation of -400 m, and

368 rises again to $\sim 0 \mathrm{~m}$ on the southern wall of Ophir Chasma. This outcrop is covered only by

369 OMEGA data at a spatial resolution of $2.5 \mathrm{~km} / \mathrm{pixel}$ and is partly overlain by smooth material,

370 but the textural similarity to outcrops further to the east suggests that it consists of kieserite and

371 is the westward prolongation of the kieserite deposits on the southern chasm wall ("MHS, in

372 situ" Fig. 5). If this is the case, this suggests that (1) at the time when light-toned deposits of

373 Ophir Mensa extended further to the south, as suggested by the monohydrated sulfates on the

374 southern wall and the southward continuation of the light-toned deposits underneath a basaltic 
375 cover described in the eastern part of the "mineral bowl" (Fig. 5), these light-toned deposits

376 never filled up the "mineral bowl" to the top of Ophir Mensa, but instead, a valley existed at the

377 location of the "tongue-shaped" deposit between Ophir Mensa and the southern wall. It also

378 suggests, that (2) the polyhydrated sulfate deposits on the southern wall discordantly superpose

379 the kieserite deposits ("MHS in situ", Fig. 5) on the southern chasm wall. Further high resolution

380 HiRISE and CRISM observations of this part of the "mineral bowl" would help to solve this

381 case.

382 The diverse mineralogy and complex depositional pattern of the LTDs on the southern wall are

383 observed at the highest spectral and spatial resolution in the CRISM observation FRT0000A86A

384 in Fig. 6. It shows ridges of kieserite in the valley cut into the chasm wall (center of Fig. 6A).

385 These ridges, which could correspond to "MHS in situ" in Fig. 5, are overlain by a sequence of

386 smooth layers corresponding to "MHS, redeposited" in Fig. 5. The smooth layers dip downslope

387 at an angle of approx. $14^{\circ}$. Polyhydrated sulfates are found concordantly on the top of the

388 smooth layers, but at the foot of the slope, they discordantly superpose and embay a massive

389 outcrop of kieserite (Fig. 7A, C). Iron oxides are mostly associated with polyhydrated sulfates,

390 but they also occur directly on top of kieserite. We analyzed the ferric oxides further using the

391 CRISM data in the visible spectrum, as described in section 2. The regions appearing red in Fig.

392 5A show very similar spectral characteristics with a broad absorption band at $0.86 \mu \mathrm{m}$ and two

393 minor bands at 0.5 and $0.58 \mu \mathrm{m}$, resembling the spectrum of red hematite (Fig. 6G). 
400 Three other mineral phases are detected in this CRISM observation as well. Phase one displays 401 spectral bands at 1.85 and $2.27 \mu \mathrm{m}$, diagnostic for jarosite, with the Fe-depleted $\mathrm{H}_{3} \mathrm{O}$-jarosite 402 (Milliken et al., 2008) being the best match (blue in Fig. 6B). It is found in several locations 403 close to polyhydrated sulfates, both in the narrow valley and near the base of the slope. In the 404 visible spectral range, this material displays an asymmetric absorption band at $0.45 \mu \mathrm{m}$, which 405 fits to an absorption feature of jarosite at $0.44 \mu \mathrm{m}$. A second phase is characterized by 406 absorptions near 1.93 and $2.21 \mu \mathrm{m}$ and a shoulder near $2.32 \mu \mathrm{m}$ (2.21-phase). Its spectrum does 407 not match any of the laboratory spectra available from RELAB. Laboratory spectra with an 408 absorption near $2.2 \mu \mathrm{m}$ include amorphous $\mathrm{SiO}_{2}$ and Al-rich phyllosilicates like montmorillonite 409 (Fig. 5). However, amorphous $\mathrm{SiO}_{2}$ shows a broad absorption band around $2.22 \mu \mathrm{m}$ and no 410 shoulder towards longer wavelengths, while montmorillonite has a narrow absorption band at $4112.21 \mu \mathrm{m}$ and shoulder near $2.27 \mu \mathrm{m}$, which makes both minerals unlikely matches. Similar 412 spectra have been reported by Roach et al., 2010b from Ius Chasma and elsewhere in Valles 413 Marineris, and have been interpreted as hydrated silica phases or mixtures of phyllosilicates, 414 amorphous silica and/or jarosite. A third phase has a very similar spectrum as the $2.21-\mu \mathrm{m}-$ 415 phase, but shows an absorption band at $2.23 \mu \mathrm{m}$. This spectrum is similar to spectra observed in 416 Aram Chaos and interpreted as a ferric hydroxysulfate (Lichtenberg et al., 2010), which was 417 produced in the laboratory by desiccation of synthetic melanterite $\left(\mathrm{Fe}^{2+} \mathrm{SO}_{4} \cdot 7\left(\mathrm{H}_{2} \mathrm{O}\right)\right)$. Unlike any 418 other spectra in this observation, this material displays an absorption band at $0.76 \mu \mathrm{m}$ (Fig. 5G). 419 The polyhydrated ferric sulfate coquimbite $\left(\mathrm{Fe}^{3+}{ }_{2}\left(\mathrm{SO}_{4}\right)_{3} \bullet 9\left(\mathrm{H}_{2} \mathrm{O}\right)\right.$, not shown $)$ has a similar band 420 near $0.76 \mu \mathrm{m}$, but its spectrum does not match in the short wave infrared range. The 2.21- $\mu \mathrm{m}-$ 
421 phase and the $2.23-\mu \mathrm{m}$-phase occur in similar stratigraphic positions. They superpose kieserite

422 deposits as a thin, very light-toned coating, and are covered by basaltic debris, as shown in Fig.

4237 and the schematic cross-sections therein. The outcrop of the 2.23- $\mu$ m-phase in Fig. 7A appears

424 to be more deeply eroded than the 2.21-phase. It therefore is interpreted as underlying the 2.21-

$425 \mu \mathrm{m}$-phase in the cross section in Fig. 7C. Polyhydrated sulfates are found in a similar

426 stratigraphic position overlying kieserite units. The basalts at the top of the ridge in Fig. 7B

427 appear blocky and layered, and thus resemble remnants of basaltic lava flows underlying the

428 sulfates rather than aeolian deposits on top of them. This ridge is very similar to ridges in the

429 west of the "mineral bowl" (white arrow in Fig. 5), suggesting that its mineralogy is present

430 elsewhere in this part of Ophir Chasma, but not detected due to the lack of high-resolution

431 spectral data.

432

433 [INSERT FIGURE 7 HERE]

\subsection{The "northern moat"}

436 The "northern moat" is the west-east-trending valley between Ophir Mensa and the northern rim

437 of Ophir Chasma. Its floor is mostly covered by landslides eroding the chasm wall. In a few

438 places, patches of light-toned material appear through windows in the landslide material cover

439 (Fig. 8). The two outcrops in Fig. 8 A and B have a texture similar to Ophir Mensa, which

440 suggests that Ophir Mensa once extended further northward. The two patches show no spectral

441 signature of sulfates, and are located at elevations of $-3100 \mathrm{~m}$ and $-3300 \mathrm{~m}$, whereas a third patch

442 of light-toned material is found at $-4600 \mathrm{~m}$. This third patch is similar in texture to the floor of

443 the central valley. Ratioed CRISM MSP and OMEGA spectra show an absorption band at 
$4441.4 \mu \mathrm{m}$, a broad feature at $1.9 \mu \mathrm{m}$ and a drop-off in reflectance longward of $2.3 \mu \mathrm{m}$, consistent

445 with polyhydrated sulfate. The similar elevation, mineralogy and texture of this outcrop and the

446 deposits in the central valley suggests that unlike the two outcrops in Fig. 8A and B, this outcrop

447 is not a remnant of Ophir Mensa, but rather an infill of the basin between Ophir Mensa and the

448 northern chasm wall, similar to the central valley fill.

[INSERT FIGURE 8 HERE]

452 Sulfates are also found within the deposits of a landslide in Fig. 9. It shows sulfate-rich material 453 at the tip of a landslide fan that was deposited against the LTDs of Ophir Mensa. Since the time 454 of deposition of this landslide, the slope of Ophir Mensa has been eroded backward 1.2 to $2.5 \mathrm{~km}$ 455 by wind, leaving behind a flat, dune-covered plain between the landslide deposit and the slope of 456 Ophir Mensa. The HRSC anaglyph in Fig. 9B suggests that the landslide deposit and the sulfate 457 material therein overlay the light-toned deposits of Ophir Mensa, as shown in the cross-section in 458 Fig. 9C. Theoretically, the sulfates could have formed prior to the landslide event, or by water 459 released by the landslide event itself. Lucchitta, 1987, argued that the landslides in the central 460 valley of Ophir Chasma released large quantitites of water, which caused the collapse of the 461 mountain barrier between Ophir and Candor Chasmata, and deepened the central valley.

462 However, Quantin et al., 2004, observed, that landslides in Valles Marineris occurred at all times 463 between $3.5 \mathrm{Ga}$ and $50 \mathrm{Ma}$ before present, and that they always show the same characteristics. 464 This suggests that no water was involved in the formation of the landslides, as the atmospheric 465 conditions during this period did not allow a sustained existence of liquid water. The topographic 466 elevation of the sulfates of $-3450 \mathrm{~m}$ is also much higher than the $-4500 \mathrm{~m}$ of the closest sulfate 
467 deposits in the "northern moat" (Fig. 8C). We therefore conclude that the sulfates in Fig. 9 were

468 formed prior to the landslide events. The ages of the landslides in Ophir Chasma range between

$46980 \mathrm{Ma}$ and $1 \mathrm{Ga}$ (Quantin et al., 2004) and provide no constraint on ILD formation and water-

470 related activity, which ended at 3 to $3.5 \mathrm{Ga}$ (Quantin et al., 2010).

471

472 [INSERT FIGURE 9 HERE]

473

\section{$474 \quad 3.5$ The central valley}

475 The floor of the central valley is partly covered by sulfate-rich deposits, as shown in Fig. 10. Its

476 surface gently drops from $-4250 \mathrm{~m}$ in the south-west to $-4900 \mathrm{~m}$ in the north-east, resulting in a

477 dip of approximately $1^{\circ}$ (Chojnacki and Hynek, 2008; Gendrin et al., 2005; Mangold et al.,

478 2007). The deposits are at least $270 \mathrm{~m}$ thick, and are easily recognized by a distinct hue in HRSC

479 false color images (fig. 10D). The CRISM observations of this area generally confirm the

480 mineralogy derived from OMEGA data. The top of the deposit is dominated by the

481 monohydrated sulfate kieserite, that is partly covered by dunes of dark-toned, basaltic material. It

482 has a rough, fluted texture with curved ridges trending approximately perpendicular to the valley

483 axis (Fig 10E, F and G). An increase of the spectral slope between 1 and $1.3 \mu \mathrm{m}$ in CRISM and

484 OMEGA spectra in the southern part of the valley indicates that the smooth material with an

485 intermediate albedo found in this part of the valley is rich in ferric oxides (fig. 10F).

486 Directly south of landslide deposits in the north of the central valley, the valley floor deposits

487 display spectra of polyhydrated sulfates. They show a fluted, wind-eroded topography (fig 10E),

488 but are devoid of the ridges found in the monohydrated sulfates (fig. 10F) and are not covered by

489 dark, basaltic dunes. The patch is topographically lower than the neighboring monohydrated- 
490 sulfate rich deposits. This suggests that monohydrated sulfates overlay polyhydrated sulfates, as

491 shown in the cross-section in Fig. 10C. The superposition of monohydrated sulfates on top of

492 polyhydrated sulfates is contrary to sulfates in the "mineral bowl" and other chasmata of Valles

493 Marineris, such as Juventae Chasma (Bishop et al., 2009; Gendrin et al., 2005) and West Candor

494 Chasma (Murchie et al., 2009a). The boundary between poly- and monohydrated sulfates is

495 gradational and coincides with a decrease in albedo from the brighter poly- to the slightly darker

496 monohydrated sulfates. However, it also coincides with an increase in the abundance of dark

497 dunes. Therefore, the albedo difference between the brighter polyhydrated sulfates and the darker

498 monohydrated (kieserite-dominated) sulfates (Chojnacki and Hynek, 2008), might be caused by

499 the presence of basaltic dunes and iron oxides in the area of the monohydrated sulfates, and not

500 by a color variation between the two sulfate species. Both sulfate species are not layered. The

501 deposit ends abruptly near the remains of the mountain barrier between Ophir and Candor

502 Chasma at $72^{\circ} \mathrm{E}, 5^{\circ} \mathrm{S}$.

503

504 [INSERT FIGURE 10 HERE]

505

506 Light-toned, often subcircular patches with a diameter of a few hundred meters are observed in

507 the northern part of the central valley, where polyhydrated minerals are found (fig. 11). They

508 show bands at $1.93 \mu \mathrm{m}, 2.21 \mu \mathrm{m}$ and $2.27 \mu \mathrm{m}$ and shoulder at $2.32 \mu \mathrm{m}$ in CRISM targeted

509 observations, which is very similar to the 2.21- $\mu \mathrm{m}$-phase observed in the "mineral bowl" (Fig. 6)

510 and Ius Chasma (Roach et al., 2010b). Again, a mixture of jarosite (possibly $\mathrm{H}_{3} \mathrm{O}$-jarosite) and

511 amorphous silica or montmorillonite is the best spectral match. A phase with a band at $2.23 \mu \mathrm{m}$

512 is not observed here. Unlike the deposits in the "mineral bowl", the deposits in the central valley 
513 are not layered, and almost indistinguishable from the surrounding deposits by their texture

514 alone.

515

516 [INSERT FIGURE 11 HERE]

517

\section{Discussion}

\section{$519 \quad 4.1$ Mineral detections}

520 Roach et al., 2010b suggested four hypotheses for the minerals showing absorption bands at

$5212.21 \mu \mathrm{m}$ observed in Ius Chasma, which are spectrally very similar to the $2.21-\mu \mathrm{m}$-phase

522 observed in Ophir Chasma: (1) a sulfate mineral structurally similar to jarosite, (2) amorphous

523 silica mixed with Fe-Mg-smectite, (3) a mixture of Al- and Fe-Mg-smectite, or (4) poorly

524 crystalline mixed Al-Fe clay formed either by acid alteration of clay minerals or as a direct

525 formation from dissolved basalt.

526 Library spectra of the three most common jarosite minerals, Na-jarosite, $\mathrm{K}$-jarosite and $\mathrm{H}_{3} \mathrm{O}$ -

527 jarosite, are very similar to the $2.21-\mu \mathrm{m}$-phase, but no perfect spectral match. Like the unknown

528 phase, they display absorptions at $1.93 \mu \mathrm{m}$ and a shoulder near $2.32 \mu \mathrm{m}$, but the band at $1.85 \mu \mathrm{m}$,

529 characteristic for jarosites, is not observed in the unknown phase. An absorption band at $2.21 \mu \mathrm{m}$

530 is observed in K-jarosite, but this mineral shows a second, deeper absorption near $2.27 \mu \mathrm{m}$,

531 which is absent or only weakly expressed in the unknown phases. Therefore, if a jarosite mineral

532 is present in these phases, it is probably mixed with a different mineral.

533 Amorphous silica displays a broad spectral band at $2.21 \mu \mathrm{m}$, and a shoulder at $2.26 \mu \mathrm{m}$. In

534 contrast, the absorption band at $2.21 \mu \mathrm{m}$ of the unknown phase is narrow, and its right shoulder 
535 is located at longer wavelengths at $2.32 \mu \mathrm{m}$, which makes pure amorphous silica a bad spectral

536 match. A mixture of Al-rich and $\mathrm{Mg} / \mathrm{Fe}-$ rich clay minerals or of clay minerals and jarosite could

537 reproduce the absorption bands observed here. However, clays form under circum-neutral $\mathrm{pH}-$

538 conditions, whereas the clear identification of jarosite in neighboring locations, and partly in

539 similar stratigraphic positions, points towards acidic conditions ( $\mathrm{pH}<3-4$, Papike et al., 2006),

540 which makes the presence of clay minerals unlikely. A theoretical alternative would be the

541 formation of clay minerals at a different location than the jarosite minerals and subsequent

542 transport to this place, but the location of the 2.21- $\mu$ m-phase high on the slopes just below the

543 crests of fresh basaltic wall rock effectively rules out this option, as it suggests a formation of

544 this phase in situ.

545 The last hypothesis is the formation as a poorly crystalline $\mathrm{Fe}-\mathrm{SiO}_{2}$-phase by acidic to neutral

546 leaching of nontronite, which would produce Si-OH vibrations due to the formation of

547 amorphous silica as in clay-rich material exposed to acidic vapors at Mauna Kea (Swayze,

548 unpublished data in Roach et al.,2010b). This mechanism would also explain the observed

$5492.23 \mu \mathrm{m}$ band observed locally during this study due to FeAlOH vibrations. Alternatively, Tosca

550 et al., 2008, report the formation of a poorly crystalline $\mathrm{Fe}-\mathrm{SiO}_{2}$-phase as a precipitate from

551 dissolved basalt by addition of $\mathrm{S}$ and $\mathrm{Cl}$ under oxidizing conditions at a $\mathrm{pH}$ of 5-7 in laboratory

552 tests, which would possibly display similar spectral bands between 2.21 and $2.26 \mu \mathrm{m}$.

553 Of the proposed mineralogies of the unknown 2.21- $\mu$ m-phase, we favor a mixture of jarosite and

554 amorphous silica or jarosite and a newly formed, poorly crystalline $\mathrm{Fe}-\mathrm{SiO}_{2}$ - phase, and a

555 mixture of jarosite and a poorly crystalline $\mathrm{Fe}-\mathrm{Al}-\mathrm{SiO}_{2}$-phase for the locations showing a

$5562.23 \mu \mathrm{m}$ absorption, rather than mixtures of different phyllosilicate minerals or phyllosilicate

557 minerals and jarosite. In the "mineral bowl" (fig. 6), the clear identification of $\mathrm{H}_{3} \mathrm{O}$-jarosite 
558 suggests acidic conditions, which are inconsistent with clay formation. Amorphous silica in

559 combination with jarosite has also been identified by CRISM on the plateau above Juventae

560 Chasma (Bishop et al., 2009; Milliken et al., 2008) and in Melas Chasma (Metz et al., 2009),

561 where they are interpreted as the product of acidic alteration of basalts.

562 On Earth, jarosite and amorphous silica are known from acid mine drainage deposits, for

563 example in Spain (i.e., Sánchez España et al., 2005) and Greece (Triantafyllidis and Skarpelis,

564 2006), where the oxidation of sulfides produces sulfuric acid, which in turn dissolves olivines,

565 pyroxenes and feldspars in the basaltic rocks to form jarosite, leaving behind amorphous silica

566 and kaolinite as the least soluble minerals. A similar mechanism has been proposed for Mars

567 (Burns, 1987; Burns and Fisher, 1990; Poulet et al., 2008). Investigations on a Martian meteorite

568 show that a part of the jarosite and amorphous silica on Mars formed under hydrothermal

569 conditions (McCubbin et al., 2009), but the $\mathrm{H}_{3} \mathrm{O}$-jarosite best matching the spectra from Ophir,

570 Melas and Juventae Chasma indicates temperatures below $100^{\circ} \mathrm{C}$ (Milliken et al., 2008). All

571 jarosite species indicate a limited water supply and short time for the chemical alteration, as the

572 acidity is not neutralized by the decomposition of feldspars (Höller, 1967; Madden et al., 2004).

$573 \mathrm{H}_{3} \mathrm{O}$-jarosite forms at even lower water/rock ratios, when sulfide minerals dissolve more rapidly

574 than rock forming minerals, resulting in a lack of $\mathrm{Na}$ and $\mathrm{K}$ with respect to $\mathrm{Fe}$ in the solution,

575 which prevents the formation of K- and Na-jarosite (Brophy and Sheridan, 1965). At rising pH,

$576 \mathrm{H}_{3} \mathrm{O}$-jarosite becomes unstable, and goethite $(\mathrm{FeOOH})$ forms, while the sulfate ions go back into

577 solution (Burns and Fisher, 1990). At the same time, poorly crystalline $\mathrm{Fe}$-or $\mathrm{FeAl}-\mathrm{SiO}_{2}$-phases

578 can form (Tosca et al., 2008), which can be considered precursors to clay minerals. Goethite can

579 later transform into hematite, while the sulfate ions could precipitate as polyhydrated sulfates

580 upon evaporation of the brine. An alternative source for the acidity required for the jarosite 
581 formation other than weathering of sulfides are volcanic, $\mathrm{SO}_{2}$-rich exhalations as observed at the

582 Kilauea volcano (Schiffman et al., 2006).

583 The mineral assemblage observed on the southern wall of Ophir Chasma (fig. 6 and 7) is

584 consistent with an acidic alteration of basaltic rock: jarosite and the unidentified, possibly

585 jarosite-amorphous silica bearing phases are almost always observed at the top of the hillsides,

586 just below the crest, locations that would have received very little water. They are covered by

587 basaltic debris, which would be the source rock. They are topographically higher than iron oxide

588 detections and polyhdrated sulfates, which would represent the more developed alteration

589 products. On the northern side of the mineral bowl, where the slopes are lacking a basaltic cover,

590 no $2.21-\mu \mathrm{m}$-phase or jarosite are found. In the central valley, the relationship between the

591 abundant polyhydrated sulfates and the patchy outcrops of the $2.21-\mu \mathrm{m}$-phase is not clear and

592 gives no hint on the formation history. A possible source rock for the sulfatic alteration products

593 cannot be identified.

\section{$594 \quad 4.2$ Stratigraphic relationships}

595 Any hypothesis for the formation of the light-toned deposits and the role of water therein has to

596 meet the constraints imposed by the stratigraphic relationships within the LTD units and between

597 the LTDs and the wall rocks. They are visualized in Fig. 12 and summarized as follows:

598 (1) All light-toned deposits in Ophir Chasma superpose the spur-and-gully morphology of the

599 canyon walls. Their deposition therefore postdates the formation of the chasm (Chojnacki and

600 Hynek, 2008).

601 (2) The LTDs of Ophir Mensa can be divided into two units based on layer boundaries and 602 mineralogy. A marker horizon (fig. 1) separates the two units. Its dip roughly follows the local 603 topography, with steep $\left(\sim 20^{\circ}\right)$ slopes at the flanks of Ophir Mensa and approx. horizontal 
604 layering in the center. This implies that the eastern part of Ophir Mensa is younger than the 605 western part.

606 (3) The lower unit of Ophir Mensa is kieserite-bearing. The strong erosion of Ophir Mensa in the

607 "mineral bowl" suggests that the kieserite signature is not a superficial deposit draped over a

608 sulfate-free rock, but that the entire lower unit contains kieserite sulfate.

609 (4) The monohydrated sulfates on the southern wall of the "mineral bowl" are connected to Ophir

610 Mensa by a "tongue" of light-toned, sulfate-rich material. This suggests that these deposits are of

611 the same age. The monohydrated sulfates in the "mineral bowl" therefore formed, when Ophir

612 Mensa extended further southward up to the southern wall of the chasm. The top of the LTDs

613 along the southern wall of Ophir Chasma dropped from west to east, as shown by remnants of

614 light-toned material on the chasm wall.

615 (5) However, at the time of sulfate formation, a precursor valley of the "mineral bowl" already

616 existed, which formed a depression between the center of Ophir Mensa and the southern wall.

617 This is shown by the (likely) sulfate-bearing "tongue" between the southern wall and Ophir

618 Mensa: It starts near the top of Ophir Mensa, drops down at its center and raises again towards

619 the southern wall (fig. 5B).

620 (6) Polyhydrated sulfates in the "mineral bowl" are found near the top of the light-toned material.

621 The transition between kieserite and polyhydrated sulfates appears concordant on the upper slope

622 of the southern wall (fig. 6 and 7), but discordant in the lower parts, where polyhydrated sulfates

623 embay an eroded remnant of kieserite-rich rock. Further westward, the polyhydrated sulfates

624 appear to discordantly overlay parts of the "tongue" between Ophir Mensa and the southern wall.

625 This implies that polyhydrated sulfates formed after the deposition and partial erosion of the

626 kieserite-rich rocks. 
627 (7) It is not clear if the polyhydrated sulfates precipitated directly in their current form, or if they

628 formed by hydration of the underlying kieserite-rich material. The presence of jarosite and

629 poorly constrained, probably amorphous silica-rich material underneath a cover of basaltic debris

630 is consistent with an acid alteration of the basaltic cover caused by the decomposition of sulfides,

631 as suggested by Burns, 1987. This would require the presence of water, which could also have

632 transformed monohydrated kieserite to polyhydrated sulfates. An alteration from kieserite to

633 polyhydrated sulfates has also been suggested for Ius Chasma (Roach et al., 2010b), whereas the

634 variation in sulfate mineralogy in Candor and Juventae Chasma has been interpreted to be caused

635 by changes of the composition of the evaporating brine (Murchie et al., 2009a, Bishop et al., 636 2009).

637 (8) Ferric oxides contained within the sulfate-rich deposits in Ophir Mensa (Bibring et al., 2007)

638 accumulate on the floor of the "mineral bowl", where they form a partly indurated lag deposit

639 together with sulfates and basaltic debris from the south wall.

640 (9) The sulfates of the central valley and the "northern moat" show distinct characteristics. They

641 formed after the incision of the central valley, and therefore post-date Ophir Mensa.

642 (10) All sulfate deposits in the central valley are found below $-4250 \mathrm{~m}$, approx. $1450 \mathrm{~m}$ below

643 the lowest sulfate detections in the "mineral bowl". Only the sulfates underneath a landslide in

644 the "northern moat" are found at higher elevations (fig. 8), but it is not clear if they formed in situ

645 or have been transported to this elevation by the landslide.

646 (11) In the central valley, monohydrated kieserite apparently stratigraphically superposes

647 polyhydrated sulfates, unlike in Candor Chasma, Aram Chaos and Juventae Chasma, where

648 monohydrated sulfates are stratigraphically below polyhydrated sulfates (Bishop et al., 2009;

649 Lichtenberg et al., 2010; Murchie et al., 2009a), but similar to Ius Chasma (Roach et al., 2010b). 
[INSERT FIGURE 12 HERE]

652

\subsection{Implications for formation hypotheses}

654 The presence of sulfates within the ILDs of Ophir Mensa indicate, that water played a role in

655 their formation. On the other hand, large parts of the ILDs are spectrally bland although they are

656 likely not covered by dust, as indicated by elevated TI values around 500 thermal inertia units

657 (Chojnacki and Hynek, 2008, fig. 2a), steep slopes and no visible small dunes in HiRISE images.

658 Therefore, these parts of the LTDs must either have formed under dry conditions that did not

659 involve water, or they are cemented by minerals that are not detectable from orbit, such as halite

$660(\mathrm{NaCl})$ or anhydrite $\left(\mathrm{CaSO}_{4}\right)$. In the following paragraphs, we will discuss the formation of the

661 ILDs in the light of our observations, before we investigate, whether the sulfates in Ophir

662 Chasma precipitated from evaporating groundwater (Roach et al., 2010b; Rossi et al., 2008) or

663 lakes (Lucchitta, 2009a; 2009b; McKay and Nedell, 1988) or meteoric water, or a combination

664 of these processes.

665 Some authors suggested that the LTDs were exhumed light-toned material from the chasm walls

666 (Adams et al., 2009; Malin and Edgett, 2000). This idea can be rejected, as the light-toned

667 material clearly overlays the spur-and-gully morphology of the chasm walls as elsewhere in

668 Valles Marinieris (Blasius et al., 1977; Lucchitta et al., 1992; Nedell et al., 1987). The idea that

669 the LTDs are subice volcanoes was proposed by Chapman and Tanaka, 2001. This theory

670 explains the outward dipping layers of the LTDs and the fact that most LTDs form free-standing

671 mounds, separated from the chasm walls by depressions. However, it implies that the LTDs are 
672 volcanic strata. This is contradictory to the lack of a basaltic spectral signature of these rocks and

673 the missing of clear volcanic morphologies such as craters or lava flows.

674 If the LTDs were eolian or pyroclastic deposits (Chapman and Tanaka, 2001; Peterson, 1981),

675 we would expect similar deposits outside Valles Marineris (Glotch and Rogers, 2007). Layered

676 deposits deposits are found on the plains surrounding Valles Marineris (Bishop et al., 2009,

677 Milliken et al., 2008, Le Deit et al., 2010), which are interpreted as airfall deposits (Le Deit et

678 al., 2010). These deposits are much thinner $(<100 \mathrm{~m})$ than the deposits within the chasmata.

679 Thus, an origin of the spectrally bland material in the LTDs by airfall, either as volcanic clasts or

680 windblown dust, is conceivable, but an additional mechanism to trap and lithify these deposits is

681 required to explain the observed thickness of the deposits (Lucchitta, 2009a, 2009b).

682 Regardless of the origin of the spectrally bland LTDs, the sulfates within them are formed by

683 water. The stratigraphic relationships described in section 4.2 require at least two phases of

684 sulfate formation. In a first phase, sulfates formed within Ophir Mensa and in a second phase the

685 in the central valley. The monohydrated sulfates on the southern wall of Ophir Chasma appear to

686 be remnants of the sulfates of Ophir Mensa, which once extended further southward. The

687 polyhydrated sulfates possibly formed later, either by alteration of the previous monohydrated

688 sulfate, or by acid weathering of the overlaying basaltic debris. The timing of this alteration

689 phase is poorly constrained. It can be contemporaneous with the sulfate formation in the central

690 valley and the northern moat, or might also have taken place independently from that event. For

691 nearby Capri Chasma, Roach et al., 2010a advocated the concept that the monohydrated kieserite

692 was not the sulfate phase that initially precipitated, but was formed later during diagenesis from

693 previously polyhydrated sulfates under the overburden of several kilometers of sediments on top.

694 The LTDs of Ophir Mensa are several kilometers thick, therefore, diagenetic processes or 
695 intrusions of brines that altered an initial mineralogy to the mineralogy now observed is possible,

696 but an assessment of their role is difficult and remains an open question.

697 The idea that the sulfates formed in lakes (Lucchitta, 2009a; 2009b; Peterson, 1981) implies that

698 the lakes acted as a trap for clastic deposits. The sulfates therefore would have formed at the

699 same time as the spectrally bland clasts hosting them. If this was the case, we would expect

700 horizontal layering and a constant upper elevation of the sulfate detection, which would resemble

701 the water level in the lake. The upper part of the LTDs, which is sulfate-free, would have been

702 formed by a different process. Therefore, the elevation variations of the upper sulfate detection

703 limit in the "mineral bowl" and the lack of sulfate detections in the LTDs at similar elevations on

704 the northern and eastern flank of Ophir Mensa are better explained by a formation by

705 groundwater (Murchie et al., 2009a) that entered the LTD mound after its deposition. In this

706 case, the variations in elevation of the sulfate detections and the coexistence of sulfate-bearing

707 and sulfate-free LTDs at the same elevation would reflect the initial morphology of the hosting

708 sediments in the chasm, or variations of their permeability.

709 The deposits in the central valley are almost horizontal, which is consistent with a formation in a

710 lake as well as a playa, similar to the mechanism proposed for Meridiani Planum (Arvidson et

711 al., 2003). The slight dip towards the north would either imply a dip of the sediments after

712 deposition, possibly by downfaulting of the entire chasm floor along the northern rim, or simply

713 deposition on an inclined chasm floor. The remnants of the collapsed mountain ridge between

714 Ophir and Candor Chasma could have acted as a barrier to form a lake behind it. The low

715 elevation of the sulfate deposit, implied by sulfate detections restricted to elevations below -4250

$716 \mathrm{~m}$, is consistent with the proposed lake in central Valles Marineris/Coprates Chasma with a

717 maximum ponding level at $-3560 \mathrm{~m}$ proposed by Harrison and Chapman, 2008. The flanks of the 
718 central valley show rills on both sides. Similar structures in Candor have been interpreted by

719 Murchie et al., 2009a, as braided channels formed by flowing water. If this was the case in Ophir

720 Chasma, they could have acted as pathways for water entering the suggested lake. The rills have

721 also been interpreted to be formed by glacial scouring (Chapman and Smellie, 2007; Roach,

722 2009), which would also be consistent with a (frozen) lake in the central valley. However, the

723 rills may also have formed by wind erosion: Many of them are not perfectly perpendicular to the

724 slope of the hillsides they form in, but curve southward. This is a strong indication for wind

725 erosion rather than flowing water or ice.

726 Like in the central valley, polyhydrated sulfates are found topographically below monohydrated

727 sulfates in western Candor Chasma and Aram Chaos (Lichtenberg et al., 2010; Murchie et al.,

728 2009a). In these locations, the polyhydrated sulfates have been interpreted as late-stage

729 sediments that were deposited discordantly in low-lying areas after erosion of the monohydrated

730 sulfates, so they would be stratigraphically above the monohydrated sulfate-rich deposits. In the

731 central valley, we do not see evidence for this interpretation. The boundary between mono- and

732 polyhydrated sulfates is transitional, and no unconformity is observed. We therefore interpret

733 that the topographically low polyhydrated sulfates are also stratigraphically below the

734 monohydrated sulfates. This stratigraphy has also been inferred for mono- and polyhydrated

735 sulfates in Ius Chasma (Roach et al., 2010b).

736 The sulfates on the southern wall of the "mineral bowl" are spread over a wide range of

737 elevations, and dip downslope. This, and the "tongue" between Ophir Mensa and the southern

738 wall, implies that the "mineral bowl" depression existed already at the time of the deposition of

739 these sulfates. Even if Ophir Mensa once extended further southward, it would already have been

740 eroded away at least partly, as otherwise the layering of the deposits on the southern wall would 
741 be more horizontal. If the sulfates were formed in a lake, this lake would have to have been deep

742 enough to form sulfates very high on the slope. In this case, other parts of this valley would have

743 been submerged at the same time, and should therefore show sulfate deposits too, which have not

744 been observed. The formation by evaporating groundwater would require that a groundwater

745 discharge from the entire slope of the chasm wall: water leaking from the top of the wall would

746 not have reached the debris deposits below the basaltic rocks on the "spurs" of the wall, where

747 some of the sulfates are found (fig. 7). The presence of high water tables in the narrow mountain

748 ridge between Ophir and Candor Chasma is also not likely. Therefore, if these deposits are

749 indeed acid alteration products of basalt, which is consistent with the spectral observations of

750 jarosite, amorphous silica, ferric oxides, polyhydrated sulfates and possibly poorly crystalline Fe-

$751 \mathrm{SiO}_{2}-$ or $\mathrm{Fe}-\mathrm{Al}-\mathrm{SiO}_{2}$-phases (the 2.21- $\mu \mathrm{m}$-phase and the 2.23- $\mu \mathrm{m}$-phase), the best way to explain

752 the supply of water to the locations where these minerals are found, would be rain, snow or frost.

754 Glaciers in Valles Marineris, which could provide the required water, and could also explain the

755 variable range of elevations where water has been present, have been proposed in previous

756 studies (Chapman and Smellie, 2007; Chapman and Tanaka, 2001; Chapman and Tanaka, 2002;

757 Mège and Bourgeois, 2010), but in this particular location, associated landforms such as U-

758 shaped valleys are missing. A second source for water could be the fog clouds in Valles

759 Marineris (i.e.,Moehlmann et al., 2009). If the Martian soil contains perchlorates, as suggested

760 by results from the Phoenix lander (Zorzano et al., 2009), these hygroscopic minerals would

761 attract water from the fog clouds in Valles Marineris and allow liquid water at temperatures as

762 low as $225^{\circ} \mathrm{K}$. However, if this is indeed the process responsible for the alteration, it remains 
763 unclear why it would be constrained to this part of Ophir Chasma only, as other parts of the

764 LTDs in the same chasm at similar elevations did not develop a spectral hydration signature.

\section{Conclusions}

766 Our study confirms and refines, based on OMEGA and CRISM data, previous studies based on

767 OMEGA data alone (Chojnacki and Hynek, 2008; Gendrin et al., 2005; Mangold et al., 2007).

768 Water-related minerals in Ophir Chasma are found mainly in two locations: In the "mineral

769 bowl" valley between Ophir Mensa and the southern wall, and on the central valley floor. The

770 same minerals are observed in these two locations, kieserite, polyhydrated sulfates, iron oxides

771 and newly discovered phases that are consistent with mixtures of jarosite and amorphous silica or

772 other poorly crystalline phases, but the two deposits are very distinct (Chojnacki and Hynek,

773 2008). In the "mineral bowl", kieserite is found in the bulk material of Ophir Mensa and on the

774 southern wall, where it could represent remnants of Ophir Mensa, which once extended further

775 southward. The variations in elevation of these sulfates are best explained by a post-depositional

776 alteration of clastic material of unknown origin, possibly airfall deposits, by ground water rather

777 than an open water body. On the southern wall, kieserite is superposed by $\mathrm{H}_{3} \mathrm{O}$-jarosite, and/or

778 possible jarosite-amorphous-silica mixtures with spectral bands at $2.21 \mu \mathrm{m}$ or $2.23 \mu \mathrm{m}$,

779 polyhydrated sulfates and iron oxides. This sulfate deposit is layered, dips downslope, is

780 stretched over a wide range of elevations, and could be stratigraphically discordant to the

781 underlying bulk LTDs. Its formation therefore possibly took place after the excavation of the

782 "mineral bowl" valley. A similar succession of polyhydrated sulfates discordantly on top of

783 monohydrated sulfates in local depositional traps has been observed in western Candor Chasma

784 and Aram Chaos (Lichtenberg et al., 2010; Murchie et al., 2009a). In Candor Chasma, rills that 
785 show similarities to braided river beds on the slopes of LTD mounds have been interpreted as

786 evidence of springs relatively high up the slopes of the chasm, which would have supplied the

787 water that eventually deposited the polyhydrated sulfates. In Ophir Chasma, locations of the

788 polyhydrated sulfates and the phases with absorptions at 2.21 or $2.23 \mu \mathrm{m}$ on ridges of the

789 underlying basaltic material is neither consistent with a water supply scenario nor with an open

790 lake: therefore, meteoric water in the form of snow, frost or fog might have played a role. Debris

791 from the LTDs, including iron oxides, are found as lag deposits on the floor of the valley, where

792 they mix with basaltic material (Bibring et al., 2007; Chojnacki and Hynek, 2008; Weitz et al.,

793 2008). On the northern side, the lack of CRISM targeted observations prevents a detailed spectral

794 analysis.

795 The sulfates in the central valley form a flat deposit at low elevations $(<-4250 \mathrm{~m})$, but appear to

796 be stratigraphically higher than Ophir Mensa's LTDs. These deposits are not layered, show

797 ridges or joints, and kieserite superposes polyhydrated sulfates. The polyhydrated sulfates

798 contain outcrops a few hundred meters in diameter of an unidentified mineral phase spectrally

799 consistent with a jarosite-amorphous-silica mixture. A deposition of these deposits in a lake,

800 possibly behind a mountain barrier that once separated Candor and Ophir Chasma, or in a playa-

801 like environment as in Meridiani Planum is conceivable.

802 The proposed succession of events is very similar to the suggested history of western Candor

803 Chasma, where the bulk of the sulfates in the LTDs is formed by intruding groundwater, and a

804 lesser amount of sulfates is formed by fluvial processes after excavation of the valleys cross-

805 cutting the ILDs by outflow events (Murchie et al., 2009a, Fig. 9). However, in Ophir Chasma,

806 the excavation of the central valley is not necessarily an outflow event, but possibly caused by

807 glaciers. We do not observe convincing evidence for fluvial activity. 
Acknowledgements

810 The authors like to thank Leah Roach and an anonymous reviewer for their comments, which

811 greatly helped to improve the manuscript. The study has been funded in part by the German

812 Space Agency (DLR Bonn) grant 50QM301 (HRSC on Mars Express) financed by the German

813 Federal Ministry of Economics and Technology and the Helmholtz Alliance "Planetary

814 Evolution and Life”. L. W. and C. G. thank Giuseppe Marzo for fruitful discussions on the

815 spectral data. P. C. M. would like to acknowledge support from the Alexander-von-Humboldt

816 Foundation and from the CRISM Science Team.

\section{$818 \quad$ References}

819

820

821

822

823

824

825

826

827

828

829

830

831

832

833

834

835

836

837

838

839

840

841

842
Adams, J. B., 1974. Visible and near-infrared diffuse reflectance spectra of pyroxenes as applied to remote sensing of solid objects in the solar system. J. Geophys. Res. 79, 4829-4836.

Adams, J. B., Gillespie, A. R., Jackson, M. P. A., Montgomery, D. R., Dooley, T. P., Combe, J. P., Schreiber, B. C., 2009. Salt tectonics and collapse of Hebes Chasma, Valles Marineris, Mars. Geology 37, 8, 691-694.

Arvidson, R. E., Seelos, F. P., Deal, K. S., Koeppen, W. C., Snider, N. O., Kieniewicz, J. M., Hynek, B. M., Mellon, M. T., Garvin, J. B., 2003. Mantled and exhumed terrains in Terra Meridiani, Mars. J. Geophys. Res. (Planets) 108, E12, 8073.

Bibring, J. P., Arvidson, R. E., Gendrin, A., Gondet, B., Langevin, Y., Le Mouelic, S., Mangold, N., Morris, R. V., Mustard, J. F., Poulet, F., Quantin, C., Sotin, C., 2007. Coupled Ferric Oxides and Sulfates on the Martian Surface. Science 317, 1206-1210.

Bibring, J. P., Soufflot, A., Berthé, M., Langevin, Y., Gondet, B., Drossart, P., Bouyé, M., Combes, M., Puget, P., Semery, A., Bellucci, G., Formisano, V., Moroz, V., Kottsov, V., Bonello, G., Erard, S., Forni, O., Gendrin, A., Manaud, N., Poulet, F., Poulleau, G., Encrenaz, T., Fouchet, T., Melchiori, R., Altieri, F., Ignatiev, N., Titov, D., Zasova, L., Coradini, A., Capacionni, F., Cerroni, P., Fonti, S., Mangold, N., Pinet, P., Schmitt, B., Sotin, C., Hauber, E., Hoffmann, H., Jaumann, R., Keller, U., Arvidson, R., Mustard, J., Forget, F., 2004, OMEGA: Observatoire pour la Minéralogie, l'Eau, les Glaces et l'Activité. Mars Express: the Scientific Payload, 37-49.

Bishop, J. L., Parente, M., Weitz, C. M., Noe Dobrea, E. Z., Roach, L. H., Murchie, S. L., McGuire, P. C., McKeown, N. K., Rossi, C. M., Brown, A. J., Calvin, W. M., Milliken, R., Mustard, J. F., 2009. Mineralogy of Juventae Chasma: Sulfates in the light-toned mounds, mafic minerals in the bedrock, and hydrated silica and hydroxylated ferric sulfate on the plateau. J. Geophys. Res. (Planets) 114. 
843

844

845

846

847

848

849

850

851

852

853

854

855

856

857

858

859

860

861

862

863

864

865

866

867

868

869

870

871

872

873

874

875

876

877

878

879

880

881

882

883

884

885

886

Blasius, K. R., Cutts, J. A., Guest, J. E., Masursky, H., 1977. Geology of the Valles Marineris First analysis of imaging from the Viking 1 orbiter primary mission. J. Geophys. Res. 82, 4067-4091.

Brophy, G. P., Sheridan, M. F., 1965. Sheridan, Sulfate studies IV: The jarosite-natrojarositehydronium jarosite solid solution series. Am. Mineral. 50, 1595-1607.

Burns, R. G., 1987. Ferric sulfates on Mars. J. Geophys. Res. 92, E570-E574.

Burns, R. G., 1993. Origin of electronic spectra of minerals in the visible to near-infrared region, in: C. M. Pieters, P. A. J. Englert, (Eds.), Remote Geochemical Analysis: Elemental and Mineralogical Composition. Cambridge University Press, New York, pp. 3-29.

Burns, R. G., Fisher, D. S., 1990. Iron-sulfur mineralogy of Mars - Magmatic evolution and chemical weathering products. J. Geophys. Res. 95, 14415-14421.

Chapman, M. G., Smellie, J. L., 2007. Mars Interior layered deposits and terrestrial sub-ice volcanoes compared: observations and interpretations of similar geomorphic characteristics. in: M. G. Chapman, (Ed.), The Geology of Mars. Cambridge University Press, Cambridge, pp. 178-210.

Chapman, M. G., Tanaka, K. L., 2001. Interior trough deposits on Mars: Subice volcanoes? J. Geophys. Res. 106, E5, 10087-10100.

Chapman, M. G., Tanaka, K. L., 2002. Related Magma-Ice Interactions: Possible Origins of Chasmata, Chaos, and Surface Materials in Xanthe, Margaritifer, and Meridiani Terrae, Mars. Icarus 155, 324-339.

Chojnacki, M., Hynek, B. M., 2008. Geological context of water-altered minerals in Valles Marineris, Mars. J. Geophys. Res. (Planets) 113, E12, 12005.

Chojnacki, M., Jakosky, B. M., Hynek, B. M., 2006. Surficial properties of landslides and surrounding units in Ophir Chasma, Mars. J. Geophys. Res. (Planets) 111, E4, 04005.

Christensen, P. R., Anderson, D. L., Chase, S. C., Clark, R. N., Kieffer, H. H., Malin, M. C., Pearl, J. C., Carpenter, J., Bandiera, N., Brown, F. G., 1992. Thermal emission spectrometer experiment - Mars Observer mission. J. Geophys. Res. 97, E5, 7719-7734.

Clark, R. N., King, T. V. V., Gorelick, N. S., 1987, Automatic continuum analysis of reflectance spectra. Third Airborne Imaging Spectrometer Data Analysis Workshop. JPL Publication, 138-142.

Clark, R. N., King, T. V. V., Klejwa, M., Swayze, G. A., Vergo, N., 1990. High spectral resolution reflectance spectroscopy of minerals. J. Geophys. Res. 95, 12653-12680.

Cloutis, E. A., Gaffey, M. J., 1991. Pyroxene spectroscopy revisited - Spectral-compositional correlations and relationship to geothermometry. J. Geophys. Res. 96, 22809-22826.

Cloutis, E. A., Hawthorne, F. C., Mertzman, S. A., Krenn, K., Craig, M. A., Marcino, D., Methot, M., Strong, J., Mustard, J. F., Blaney, D. L., Bell, J. F., Vilas, F., 2006. Detection and discrimination of sulfate minerals using reflectance spectroscopy. Icarus 184, 121157.

Dumke, A., Spiegel, M., van Gasselt, S., Neu, D., Neukum, G., 2010, Systematic Processing of High-Resolution Digital Terrain Model Quadrangles on the Basis of Mars-Express HRSC Data. Lunar Planet. Sci. 41, 1980.

Gendrin, A., Mangold, N., Bibring, J.-P., Langevin, Y., Gondet, B., Poulet, F., Bonello, G., Quantin, C., Mustard, J., Arvidson, R., LeMouélic, S., 2005. Sulfates in Martian Layered Terrains: The OMEGA/Mars Express View. Science 307, 5715, 1587-1591. 
Glotch, T. D., Rogers, A. D., 2007. Evidence for aqueous deposition of hematite- and sulfaterich light-toned layered deposits in Aureum and Iani Chaos, Mars. J. Geophys. Res. (Planets) 112, E6, 06001.

Gwinner, K., Hauber, E., Jaumann, R., Neukum, G., 2000. High-resolution, digital photogrammetric mapping: A tool for Earth science. EOS Transactions 81, 513-513.

Harrison, K. P., Chapman, M. G., 2008. Evidence for ponding and catastrophic floods in central Valles Marineris, Mars. Icarus 198, 351-364.

Höller, H., 1967. Experimentelle Bildung von Alunit-Jarosit durch die Einwirkung von Schwefelsäure auf Mineralien und Gesteine. Contrib. Mineral. Petrol. 15, 4, 309-329.

Kneissl, T., van Gasselt, S., Neukum, G., 2010, Measurement of Strike and Dip of Geologic Layers from Remote Sensing Data - New Software Tool for ArcGIS. Lunar Planet. Sci. $41,1640$.

Komatsu, G., Geissler, P. E., Strom, R. G., Singer, R. B., 1993. Stratigraphy and erosional landforms of layered deposits in Valles Marineris, Mars. J. Geophys. Res. 98, E6, 11105 - 11121.

Le Deit, L., Bourgeois, O., Mège, D., Hauber, E., Le Mouélic, S., Massé, M., Jaumann, R., Bibring, J. P., 2010. Morphology, stratigraphy, and mineralogical composition of a layered formation covering the plateaus around Valles Marineris, Mars: Implications for its geological history. Icarus 208, 684-703.

Le Deit, L., Le Mouélic, S., Bourgeois, O., Combe, J.-P., Mège, D., Sotin, C., Gendrin, A., Hauber, E., Mangold, N., Bibring, J.-P., 2008. Ferric oxides in East Candor Chasma, Valles Marineris (Mars) inferred from analysis of OMEGA/Mars Express data: Identification and geological interpretation. J. Geophys. Res. (Planets) 113, 07001.

LeDeit, L., 2008, Les dépôts stratifiés dans la région de Valles Marineris (Mars): composition minéralogique et morphologie. Faculté de Sciences et des Techniques. Université de Nantes, Nantes, 288.

Lichtenberg, K. A., Arvidson, R. E., Morris, R. V., Murchie, S. L., Bishop, J. L., Fernandez Remolar, D., Glotch, T. D., Noe Dobrea, E., Mustard, J. F., Andrews-Hanna, J., Roach, L. H., 2010. Stratigraphy of hydrated sulfates in the sedimentary deposits of Aram Chaos, Mars. J. Geophys. Res. 115, E00D17.

Loizeau, D., Mangold, N., Poulet, F., Bibring, J. P., Gendrin, A., Ansan, V., Gomez, C., Gondet, B., Langevin, Y., Masson, P., Neukum, G., 2007. Phyllosilicates in the Mawrth Vallis region of Mars. J. Geophys. Res. (Planets) 112, E8.

Lucchitta, B. K., 1987. Valles Marineris, Mars - Wet debris flows and ground ice. Icarus 72, 411-429.

Lucchitta, B. K., 1999. Geologic Map of Ophir and Central Candor Chasmata (MTM -5072) of Mars. U. S. Geological Survey,

Lucchitta, B. K., 2002, Late Mafic Volcanism in Valles Marineris, Mars. Lunar Planet. Sci. 40, 1636.

Lucchitta, B. K., 2009a, Lakes in Valles Marineris, Mars (I): Walls, Mounds, Moats, and Volcanoes. Lunar Planet. Sci. 40, 2068.

Lucchitta, B. K., 2009b, Lakes in Valles Marineris, Mars (II): Valleys, Channels, Shallow Lakes, and Age. Lunar Planet. Sci., 2345.

Lucchitta, B. K., McEwen, A. S., Clow, G. D., Geissler, P. E., Singer, R. B., Schultz, R. A., Squyres, S. W., 1992. The canyon system on Mars. Mars, pp. 453-492. 
932

933

934

935

936

937

938

939

940

941

942

943

944

945

946

947

948

949

950

951

952

953

954

955

956

957

958

959

960

961

962

963

964

965

966

967

968

969

970

971

972

973

974

975

976

977

Madden, M. E., Bodnar, R. J., Rimstidt, J. D., 2004. Jarosite as an indicator of water-limited chemical weathering on Mars. Nature 431, 821-823.

Malin, M. C., Bell, J. F., Cantor, B. A., Caplinger, M. A., Calvin, W. M., Clancy, R. T., Edgett, K. S., Edwards, L., Haberle, R. M., James, P. B., Lee, S. W., Ravine, M. A., Thomas, P. C., Wolff, M. J., 2007. Context Camera Investigation on board the Mars Reconnaissance Orbiter. J. Geophys. Res. (Planets) 112, E5.

Malin, M. C., Danielson, G. E., Ingersoll, A. P., Masursky, H., Veverka, J., Ravine, M. A., Soulanille, T. A., 1992. Mars Observer camera. J. Geophys. Res. 97, 7699-7718.

Malin, M. C., Edgett, K. S., 2000. Sedimentary Rocks of Early Mars. Science 290, 5498, 1927 1937.

Mangold, N., Gendrin, A., Gondet, B., Lemouelic, S., Quantin, C., Ansan, V., Bibring, J.-P., Langevin, Y., Masson, P., Neukum, G., 2008. Spectral and geological study of the sulfate-rich region of West Candor Chasma, Mars. Icarus 194, 519-543.

Mangold, N., Gendrin, A., Quantin, C., Bibring, J. P., Gondet, B., Langevin, Y., Poulet, F., Arvidson, R., Griffes, J. L., Hauber, H., Masson, P., Neukum, G., Omega, T., Team, H. C.-I., 2007. An Overview of the Sulfates Detected in the Equatorial Regions by the OMEGA/MEx Spectrometer. LPI Contributions 1353, 3141.

McCord, T. B., Adams, J. B., Bellucci, G., Combe, J. P., Gillespie, A. R., Hansen, G., Hoffmann, H., Jaumann, R., Neukum, G., Pinet, P., Poulet, F., Stephan, K., 2007. Mars Express High Resolution Stereo Camera spectrophotometric data: Characteristics and science analysis. J. Geophys. Res. (Planets) 112, E6.

McCubbin, F. M., Tosca, N. J., Smirnov, A., Nekvasil, H., Steele, A., Fries, M., Lindsley, D. H., 2009. Hydrothermal jarosite and hematite in a pyroxene-hosted melt inclusion in martian meteorite Miller Range (MIL) 03346: Implications for magmatic-hydrothermal fluids on Mars. Geochim. Cosmochim. Acta 73, 4907-4917.

McEwen, A. S., Eliason, E. M., Bergstrom, J. W., Bridges, N. T., Hansen, C. J., Delamere, W. A., Grant, J. A., Gulick, V. C., Herkenhoff, K. E., Keszthelyi, L., Kirk, R. L., Mellon, M. T., Squyres, S. W., Thomas, N., Weitz, C. M., 2007. Mars Reconnaissance Orbiter's High Resolution Imaging Science Experiment (HiRISE). J. Geophys. Res. (Planets) 112, E5.

McGuire, P. C., Bishop, J. L., Brown, A. J., Fraeman, A. A., Marzo, G. A., Frank Morgan, M., Murchie, S. L., Mustard, J. F., Parente, M., Pelkey, S. M., Roush, T. L., Seelos, F. P., Smith, M. D., Wendt, L., Wolff, M. J., 2009. An improvement to the volcano-scan algorithm for atmospheric correction of CRISM and OMEGA spectral data. Planet. Space Sci. 57, 809-815.

McKay, C. P., Nedell, S. S., 1988. Are there carbonate deposits in the Valles Marineris, Mars? Icarus 73, Jan. 1988, 142-148.

Mège, D., Bourgeois, O., 2010, Destabilization of Valles Marineris Wallslopes by Retreat of Ancient Glaciers. Lunar Planet. Sci. 41, 1713.

Metz, J. M., Grotzinger, J. P., Mohrig, D., Milliken, R., Prather, B., Pirmez, C., McEwen, A. S., Weitz, C. M., 2009. Sublacustrine depositional fans in southwest Melas Chasma. J. Geophys. Res. (Planets) 114, 10002.

Milliken, R. E., Swayze, G., Arvidson, R. E., Bishop, J. L., Clark, R. N., Ehlmann, B. L., Grotzinger, J., Morris, R. V., Murchie, S. L., Mustard, J. F., Weitz, C. M., Team, C. S., 2008. Spectral Evidence for Sedimentary Silica on Mars. Lunar Planet. Sci. 39, 2025.

Moehlmann, D. T. F., Niemand, M., Formisano, V., Savijärvi, H., Wolkenberg, P., 2009. Fog phenomena on Mars. Planet. Space Sci. 57, 1987-1992. 
978

979

980

981

982

983

984

985

986

987

988

989

990

991

992

993

994

995

996

997

998

999

1000

1001

1002

1003

1004

1005

1006

1007

1008

1009

1010

1011

1012

1013

1014

1015

1016

1017

1018

1019

1020

1021

1022

1023

Murchie, S., Arvidson, R., Bedini, P., Beisser, K., Bibring, J. P., Bishop, J., Boldt, J., Cavender, P., Choo, T., Clancy, R. T., Darlington, E. H., Des Marais, D., Espiritu, R., Fort, D., Green, R., Guinness, E., Hayes, J., Hash, C., Heffernan, K., Hemmler, J., Heyler, G., Humm, D., Hutcheson, J., Izenberg, N., Lee, R., Lees, J., Lohr, D., Malaret, E., Martin, T., McGovern, J. A., McGuire, P., Morris, R., Mustard, J., Pelkey, S., Rhodes, E., Robinson, M., Roush, T., Schaefer, E., Seagrave, G., Seelos, F., Silverglate, P., Slavney, S., Smith, M., Shyong, W. J., Strohbehn, K., Taylor, H., Thompson, P., Tossman, B., Wirzburger, M., Wolff, M., 2007. Compact Reconnaissance Imaging Spectrometer for Mars (CRISM) on Mars Reconnaissance Orbiter (MRO). J. Geophys. Res. (Planets) 112, E5.

Murchie, S., Roach, L., Seelos, F., Milliken, R., Mustard, J., Arvidson, R., Wiseman, S., Lichtenberg, K., Andrews-Hanna, J., Bishop, J., Bibring, J.-P., Parente, M., Morris, R., 2009a. Evidence for the origin of layered deposits in Candor Chasma, Mars, from mineral composition and hydrologic modeling. J. Geophys. Res. (Planets) 114, E12.

Murchie, S. L., Mustard, J. F., Ehlmann, B. L., Milliken, R. E., Bishop, J. L., McKeown, N. K., Noe Dobrea, E. Z., Seelos, F. P., Buczkowski, D. L., Wiseman, S. M., Arvidson, R. E., Wray, J. J., Swayze, G., Clark, R. N., Des Marais, D. J., McEwen, A. S., Bibring, J.-P., 2009b. A synthesis of Martian aqueous mineralogy after 1 Mars year of observations from the Mars Reconnaissance Orbiter. J. Geophys. Res. 114.

Murchie, S. L., Seelos, F. P., Hash, C. D., Humm, D. C., Malaret, E., McGovern, J. A., Choo, T. H., Seelos, K. D., Buczkowski, D. L., Morgan, M. F., Barnouin-Jha, O. S., Nair, H., Taylor, H. W., Patterson, G. W., Harvel, C. A., Mustard, J. F., Arvidson, R. E., McGuire, P., Smith, M. D., Wolff, M. J., Titus, T. N., Bibring, J.-P., Poulet, F., 2009c. Compact Reconnaissance Imaging Spectrometer for Mars investigation and data set from the Mars Reconnaissance Orbiter's primary science phase. J. Geophys. Res. 114, E00D07.

Nedell, S. S., Squyres, S. W., Andersen, D. W., 1987. Origin and evolution of the layered deposits in the Valles Marineris, Mars. Icarus 70, June 1987, 409-441.

Neukum, G., Jaumann, R., 2004, HRSC: the High Resolution Stereo Camera of Mars Express. Mars Express: the Scientific Payload, 17-35.

Papike, J. J., Karner, J. M., Shearer, C. K., 2006. Comparative planetary mineralogy: Implications of martian and terrestrial jarosite. A crystal chemical perspective. Geochim. Cosmochim. Acta 70, 1309-1321.

Parente, M., 2008, A New Approach to Denoising CRISM Images. Lunar Planet. Sci., 2528.

Pelkey, S. M., Mustard, J. F., Murchie, S., Clancy, R. T., Wolff, M., Smith, M., Milliken, R., Bibring, J. P., Gendrin, A., Poulet, F., Langevin, Y., Gondet, B., 2007. CRISM multispectral summary products: Parameterizing mineral diversity on Mars from reflectance. J. Geophys. Res. (Planets) 112, E8.

Peterson, C. M., 1981, Hebes Chasma - Martian Pyroclastic Sink. Lunar Planet. Sci., 828-829.

Poulet, F., Arvidson, R. E., Gomez, C., Morris, R. V., Bibring, J. P., Langevin, Y., Gondet, B., Griffes, J., 2008. Mineralogy of Terra Meridiani and western Arabia Terra from OMEGA/MEx and implications for their formation. Icarus 195, 106-130.

Quantin, C., Allemand, P., Mangold, N., Delacourt, C., 2004. Ages of Valles Marineris (Mars) landslides and implications for canyon history. Icarus 172, 555-572.

Quantin, C., Mangold, N., Hauber, E., Flahaut, J., Le Deit, L., Fueten, F., Zegers, T., 2010. Timing Constrains of Interior Layered Deposit Emplacement in Valles Marineris. First International Conference on Mars Sedimentology and Stratigraphy, 53. 
1024

1025

1026

1027

1028

1029

1030

1031

1032

1033

1034

1035

1036

1037

1038

1039

1040

1041

1042

1043

1044

1045

1046

1047

1048

1049

1050

1051

1052

1053

1054

1055

1056

1057

1058

1059

1060

1061

1062

1063

1064

1065
Roach, L. H., 2009, Sulfates in Valles Marineris as Indicators of the Aqueous Evolution of Mars. Department of Geological Sciences. Brown University, Providence, RI 296.

Roach, L. H., Mustard, J. F., Lane, M. D., Bishop, J. L., Murchie, S. L., 2010a. Diagenetic haematite and sulfate assemblages in Valles Marineris. Icarus 207, 659-674.

Roach, L. H., Mustard, J. F., Swayze, G., Milliken, R. E., Bishop, J. L., Murchie, S. L., Lichtenberg, K., 2010b. Hydrated mineral stratigraphy of Ius Chasma, Valles Marineris. Icarus 206, 253-268.

Rossi, A. P., Neukum, G., Pondrelli, M., van Gasselt, S., Zegers, T., Hauber, E., Chicarro, A., Foing, B., 2008. Large-scale spring deposits on Mars? J. Geophys. Res. (Planets) 113, E8.

Sánchez España, J., López Pamo, E., Santofimia, E., Aduvire, O., Reyes, J., Barettino, D., 2005. Acid mine drainage in the Iberian Pyrite Belt (Odiel river watershed, Huelya, SW Spain): Geochemistry, mineralogy and environmental implications. Appl. Geochem. 20, 7, 13201356.

Schiffman, P., Zierenberg, R., Marks, N., Bishop, J. L., Darby Dyar, M., 2006. Acid-fog deposition at Kilauea volcano: A possible mechanism for the formation of siliceoussulfate rock coatings on Mars. Geology 34, 921.

Sherman, D. M., Burns, R. G., Mee Burns, V., 1982. Spectral characteristics of the iron oxides with application to the Martian bright region mineralogy. J. Geophys. Res. 87, 1016910180.

Sunshine, J. M., Pieters, C. M., 1990, Extraction of Compositional Information from Olivine Reflectance Spectra: A New Capability for Lunar Exploration. Lunar Planet. Sci. 30, 1223.

Tosca, N. J., Milliken, R. E., Michel, F. M., 2008. Smectite Formation on Early Mars: Experimental Constraints. LPI Contributions 1441, 77-78.

Triantafyllidis, S., Skarpelis, N., 2006. Mineral formation in an acid pit lake from a highsulfidation ore deposit: Kirki, NE Greece. J. Geochem. Explor. 88, 1-3, 68-71.

Weitz, C. M., Lane, M. D., Staid, M., Dobrea, E. N., 2008. Gray hematite distribution and formation in Ophir and Candor chasmata. J. Geophys. Res. (Planets) 113, 02016.

Williams, D. A., Greeley, R., Fergason, R. L., Kuzmin, R., McCord, T. B., Combe, J.-P., Head, J. W., Xiao, L., Manfredi, L., Poulet, F. o., Pinet, P., Baratoux, D., Plaut, J. J., Raitala, J., Neukum, G., the, H. C.-I. T., 2009. The Circum-Hellas Volcanic Province, Mars: Overview. Planet. Space Sci. 57, 895-916.

Zegers, T. E., Dabekaussen, W., Hauber, E., Gwinner, K., Scholten, F., Fueten, F., Stesky, R., MacKinnon, P., Neukum, G., Team, H. C.-I., 2006, 3D Structural Analysis of Ophir Chasma Based on HRSC Image Data and Stereo-derived DTM. Lunar and Planet. Sci. 36, 1605.

Zorzano, M. P., Mateo-Martí, E., Prieto-Ballesteros, O., Osuna, S., Renno, N., 2009. Stability of liquid saline water on present day Mars. Geophys. Res. Lett. 36. 
1066

1067

1068

1069

1070

1071

1072

1073

1074

1075

1076

\section{[TABLES]}

Table 1: List of CRISM and OMEGA observations used in this study

\begin{tabular}{lll}
\hline $\begin{array}{l}\text { CRISM targeted } \\
\text { observations }^{\mathrm{a}}\end{array}$ & $\begin{array}{l}\text { CRISM Multispectral } \\
\text { Mapping Strips }^{\mathrm{a}}\end{array}$ & OMEGA observations $^{\mathrm{b}}$ \\
\hline FRT000082C5_07 & MSP000031C3_05 & $0548 \_3$ \\
FRT000096E6_07 & MSP000032FE_05 & 1180_5 \\
FRT0000A86A_07 & MSP000033F3_07 & 1202_1 \\
FRT0000AD8D_07 & MSP000034E0_05 & 1213_2 \\
FRT0000B27B_07 & MSP00003899_01 & 3228_3 \\
FRT0000B994_07 & MSP00003A47_01 & 4358_3 \\
FRT0000BB63_07 & MSP00003EA9_05 & 4380_3 \\
FRT000109E5_07 & MSP00004044_07 & \\
HRL0000508A_07 & MSP0000416B_05 & \\
HRL00005B82_07 & MSP000046F2_07 & \\
HRL00007468_07 & MSP00004825_01 & \\
HRL000075E7_07 & MSP00004AA1_01 & \\
HRL00007E21_07 & MSP00005575_03 & \\
HRL0000A432_07 & MSP000059A0_05 \\
HRL0000B7D4_07 & MSP00006CCB_01 \\
HRL0000BF5E_07 & MSP0000CB50_01 \\
HRL0000C30D_07 & & \\
HRL0000C59C_07 & &
\end{tabular}

${ }^{a}$ The first three characters of the CRISM file names designate the type of observation: full(FRT) or half resolution targeted (HRL) observation or multispectral mapping strip (MSP). The next characters are unique hexadecimal identifiers for each observation. The last two figures indicate the component image used from that observation. ${ }^{\mathrm{b}}$ OMEGA observations are identified by the four-digit orbit number followed by the sequence number within that orbit 
1077

1078

1079 Figure 1

1080 A: Color mosaic of HRSC orbits 334 and 3127 of Ophir Chasma with location names and

1081 simplified geologic units. Contour lines every $500 \mathrm{~m}$ from HRSC DTM with $150 \mathrm{~m}$ post spacing.

1082 Dashed red line: Prominent marker horizon in Ophir Mensa, separating it in a lower and upper

1083 unit. Local layer strike and dip measurements. Compare to Zegers et al., 2006.

1084 B: HRSC nadir mosaic with contour lines for orientation, overlain with ratio of reflectance at 1

1085 and $1.3 \mu \mathrm{m}$ ', SINDEX and BD2100 as RGB image from OMEGA and CRISM multispectral and

1086 targeted observations, and resulting mineralogic units (white lines). Iron oxides appear red,

1087 polyhydrated sulfates green, monohydrated sulfates blue.

1088

1089 Figure 2

1090 Details of the horizon marked red in Fig. 1. In the west of Ophir Mensa, it forms a steep cliff

1091 near the top of the mound (A). In the center of Ophir Mensa, it plunges at angles around $4^{\circ}$ under

1092 the overlying LTDs further east and north (B). CTX images P02_002208_1748,

1093 P12_005676_1746,P15_006955_1746.

1094

1095 Figure 3

1096 A: CTX observation P20_008893_1762 from western Ophir Mensa, overlain with spectral 1097 indices from CRISM FRT0000B27B as in Fig. 1, showing presence of kieserite (blue) and a

1098 weak presence of polyhydrated sulfates (green). The red stripe is an artifact.

1099 B: Detail of HiRISE observation PSP_008458_1760. MHS: monohydrated sulfates. The kieserite 1100 detection boundary is controlled by dust cover and oblique to layering, suggesting that kieserite 
1101 is abundant in this part of Ophir Mensa despite spatially limited detections, whereas the area

1102 showing the PHS signature is stronger affected by dust.

1103

1104 Figure 4

1105 A: HRSC orbit 334 of the "mineral bowl" overlain with HRSC contours and spectral indices as

1106 in fig. 1. Red dashed line: Prominent horizon in Ophir Mensa. Sulfate detections are restricted to

1107 units below this horizon.

1108 B: Interpreted mineralogic map of same region. MHS: monohydrated sulfates. PHS:

1109 Polyhydrated sulfates.

1111 Figure 5

1112 A: Detail of fig 4 showing the complex stratigraphic relationship between Ophir Mensa, LTDs

1113 on southern chasm wall and basaltic wall rock (CTX P12_005676_1746 and P13_006243_1746

1114 overlain on HRSC color image orbit 3127) North is left. Mineralogy as in Fig. 4, combined with

1115 geomorphologic interpretation. MHS: monohydrated sulfates. PHS: polyhydrated sulfates. White

1116 arrow: Light-toned material on ridge of southern wall. Black arrow: "Tongue" of LTD bridging a

1117 valley between Ophir Mensa and southern wall. This implies that a depression already existed at

1118 this location at the time of sulfate deposition (see text). B: Anaglyph from HRSC orbit 3127 of

1119 the same area.

1120 Figure 6

1121 A: CTX observation P03_002208_1748 and P12_005676_1746 of LTDs on southern chasm wall

1122 overlain with spectral indices from FRT0000A86A as in fig. 1. Contours from HRSC DTM.

1123 LTDs form deposits on top of basaltic wall rock. Layered kieserite is superposed by

1124 polyhydrated sulfates and iron oxides. Layers dip downslope. At base of slope, polyhydrated 
1125 sulfates embay kieserite, suggesting discordant deposition. B: Same as A, but spectral indices

1126 BD2210, BD2230 and ratio between reflectance at $2.33 \mu \mathrm{m}$ and $2.28 \mu \mathrm{m}$ as red, green and blue

1127 color planes. C: locations, where average spectra were taken. Spectra were averaged over tens to

1128 thousands of pixels to reduce noise, and divided by a spectrally inconspicuous reference region

1129 (black). D: Average reflectance spectra of monohydrated sulfates, polyhydrated sulfates, iron

1130 oxides and reference. E: Same spectra as D, ratioed to reflectance spectrum, and matching library

1131 spectra from RELAB. F: Average reflectance spectra of the three spectrally distinct regions in B,

1132 in the range of $0.41 \mu \mathrm{m}$ to $2.6 \mu \mathrm{m}$, together with ferric oxide spectrum and reference for

1133 comparison. Three phases are observed: A phase with absorption band at $2.21 \mu \mathrm{m}$ (magenta),

1134 one with a band at $2.23 \mu \mathrm{m}$ (green) jarosite (cyan). G: Ratioed reflectance spectra in the range of

11350.41 to $0.64 \mu \mathrm{m}$ and 0.69 to $0.97 \mu \mathrm{m}$ with separately removed continuum, and resembling

1136 laboratory spectra. H: Same spectra as in F and G (except ferric oxide), in the spectral range 1 -

$11372.6 \mu \mathrm{m}$, ratioed to reference region spectrum. Spectra resemble jarosite/ $\mathrm{H}_{3} \mathrm{O}$-jarosite mixed with

1138 amorphous silica or Al-rich clays (montmorillonite). Library spectra from RELAB, except $\mathrm{H}_{3} \mathrm{O}-$

1139 jarosite from Milliken et al., 2008.

$1141 \quad$ Figure 7

1142 A: Details of LTD at the foot of southern chasm wall (HiRISE anaglyph of ESP_011662_1750

1143 and ESP_011807_1750). B: Detail of ridge in Fig. 6. The 2.21-micron-phase overlays kieserite

1144 as a thin, very bright coating. Its cccurrence is restricted to the talus deposit underneath fresh

1145 basaltic ridge. A water supply to this location from groundwater or by a lake is inconsistent.

1146 Instead, water might have precipitated as rain, frost or snow from above. (HiRISE

1147 ESP_011807_1750_COLOR). C: Interpretative cross-sections to A and B (not to scale). The 
$1148 \quad 2.21-\mu \mathrm{m}$-phase, the $2.23-\mu \mathrm{m}$-phase and the polyhydrated sulfates are found in similar positions

1149 discordantly superposing MHS. The relationship among these phases is unclear due to basaltic

1150 cover. Ferric oxides are found in association with PHS.

1152 Figure 8

1153 Outcrops of light-toned material underneath landslide deposit cover in "northern moat". A and B:

1154 Sulfate-free LTDs at elevations of 3100 and $3300 \mathrm{~m}$ below datum.

1155 C: Sulfate-bearing LTD at elevation $-4600 \mathrm{~m}$. Possible floor of "northern moat" prior to

1156 landslides. (CTX images P12_005676_1746, P03_002208_1748, P18_007891_1742; contours:

1157 HRSC).

1159 Figure 9

1160 A: Sulfate deposits in landslide superposed on now partly eroded LTD of Ophir Mensa (CTX 1161 P03_002208_1748; spectral indices as in fig. 1).

1162 B: Anaglyph from HRSC orbit 2083 visualizing the stratigraphy. C Interpretative cross-section 1163 of landslide based on HRSC DTM showing sulfates overlaying Ophir Mensa LTD.

1165 Figure 10

1166 A: HRSC nadir (orbit 334) and contours of the central valley of Ophir Chasma overlain with

1167 spectral indices as in fig. 1.

1168 B: HRSC color image with interpreted mineralogy. MHS: Monohydrated sulfates. Polyhydrated

1169 sulfates are found in north of central valley. They are overlain by monohydrated sulfates

1170 (kieserite), iron oxides accumulating in the southern part of the valley, and basaltic dunes. 
1171 C: Interpretative longitudinal profile of central valley. Monohydrated sulfates superpose

1172 polyhydrated sulfates.

1173 D: Sulfates are revealed in HRSC color data by their distinct hue.

1174 E: Fluted surface texture of polyhydrated sulfates. (HiRISE PSP_007535_1755_RED)

1175 F: Ridged surface texture of kieserite-bearing valley floor, covered by basaltic dunes (SE of

1176 figure) and iron-oxide rich deposits (SW of figure; CTX P20_008972_1756).

1177 G: Example of curvilinear, sulfate-bearing ridges. Spectral indices from CRISM HRL0000B7D4

1178 as in fig. 1 on HiRISE PSP_009183_1750

1180 Figure 11

1181 A: Spectral index BD2210 of two CRISM HRL observations overlain on CTX images of the 1182 northern central valley (CTX P05_003131_1747, P20_008972_1756), and exemplary spectra.

1183 Spectra resemble jarosite with additional phases mixed in (compare fig. 6).

1184 B and C: Outcrops of the $2.21 \mu \mathrm{m}$ phase here are subcircular and almost indistinguishable in 1185 texture from the surrounding sulfate-rich rock

1187 Figure 12

1188 Suggested succession of events in Ophir Chasma. 1: Opening of Valles Marineris. 2: Deposition

1189 of the LTDs such as Ophir Mensa, possibly as airfall deposits or ash. 3: Formation of kieserite in

1190 Ophir Mensa by intruding groundwater. 4: Excavation of the "mineral bowl", "central valley"

1191 and "northern moat". 5: Deposition and/or alteration to form polyhydrated sulfates and other

1192 phases in "mineral bowl", possibly by precipitation water. Deposition of PHS and MHS (6) in

1193 "central valley", possibly in lake or underneath a glacier. The relative timing of these events is 
1194 not constrained and could coincide with deposition of layered deposits with similar mineralogy

1195 on the plateau above Valles Marineris. 7: Landslides enlarge the chasm and partly cover the

1196 floor.

1197

1198

1199 [Figures]

$1200 \quad$ [Figure 1] 


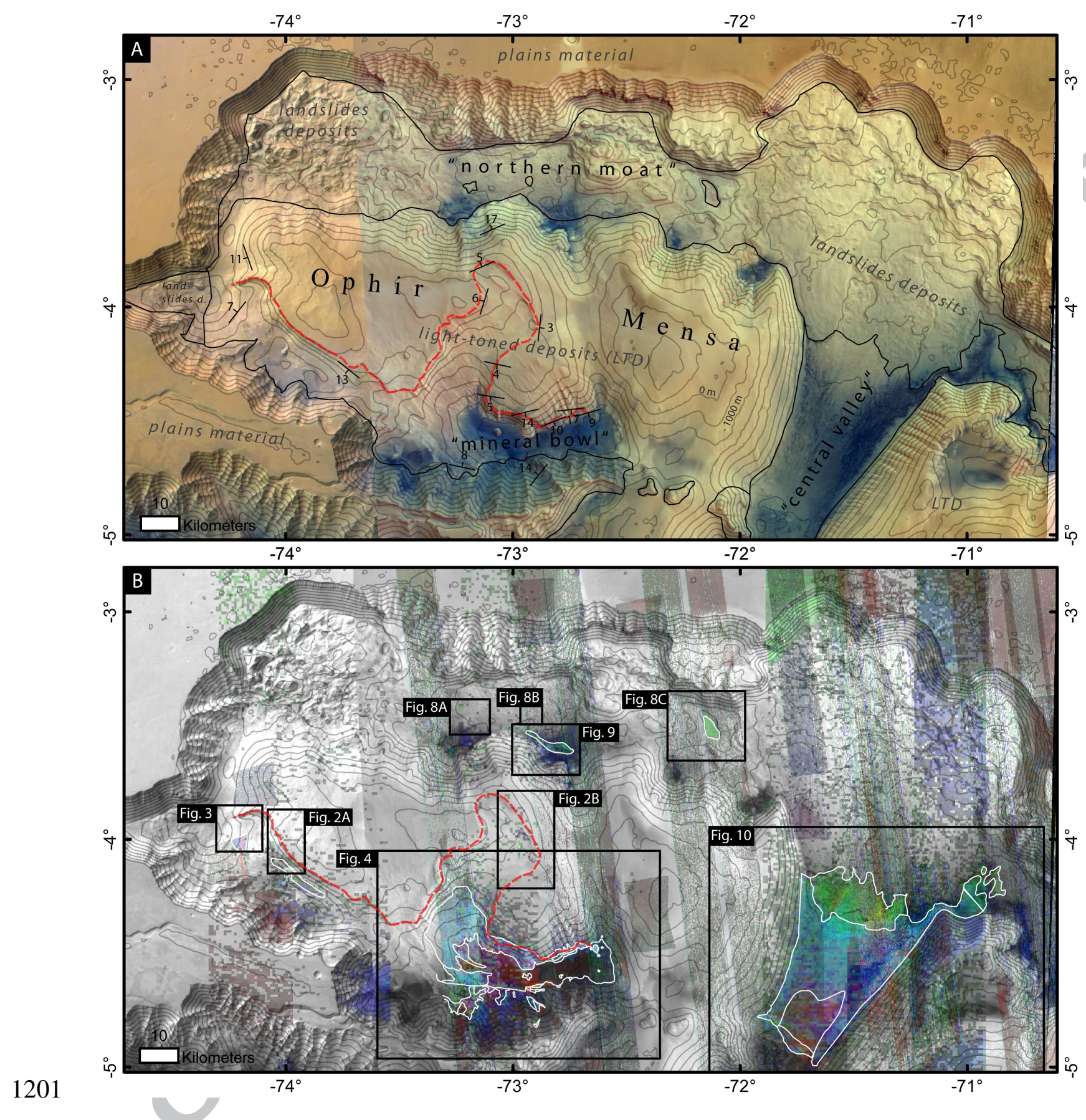

1202 [Figure 2] 


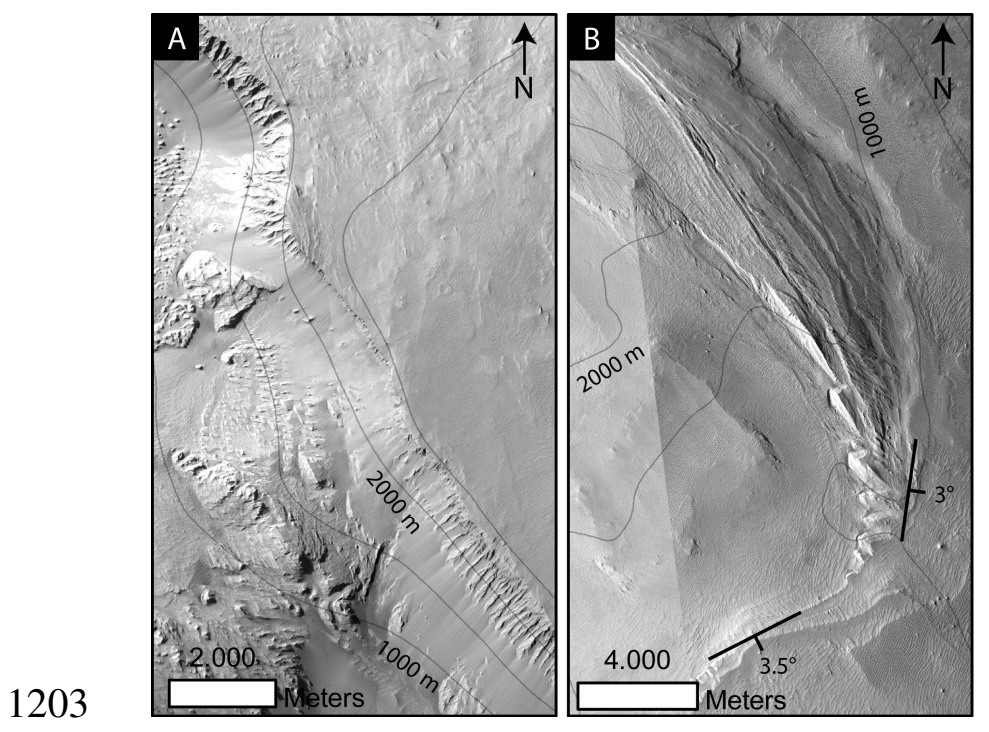

1204

1205 [Figure 3]

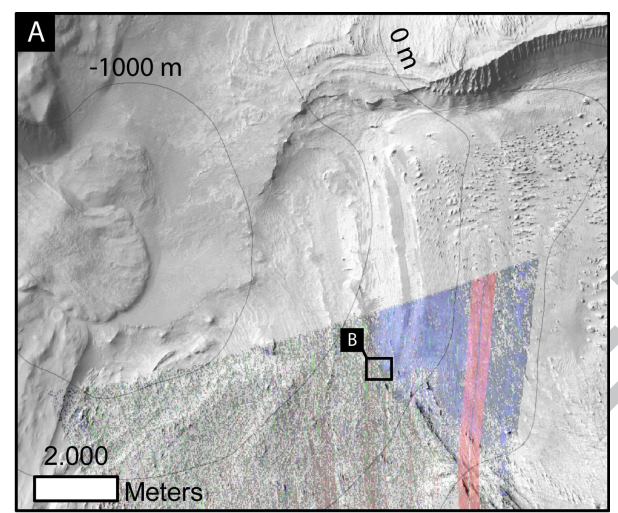

1206

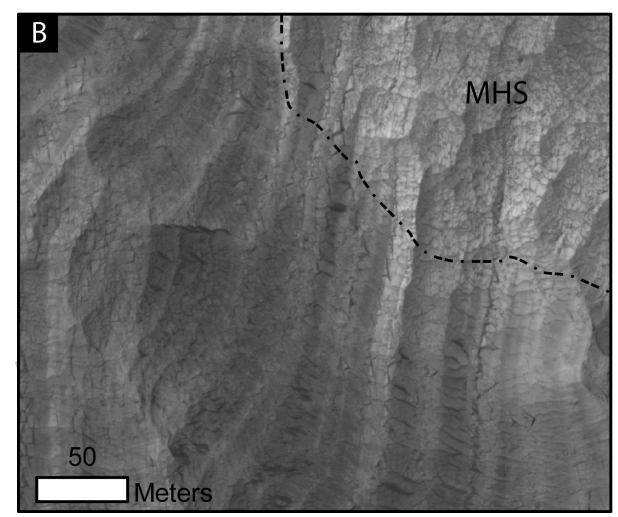

1207

1208 [Figure 4] 


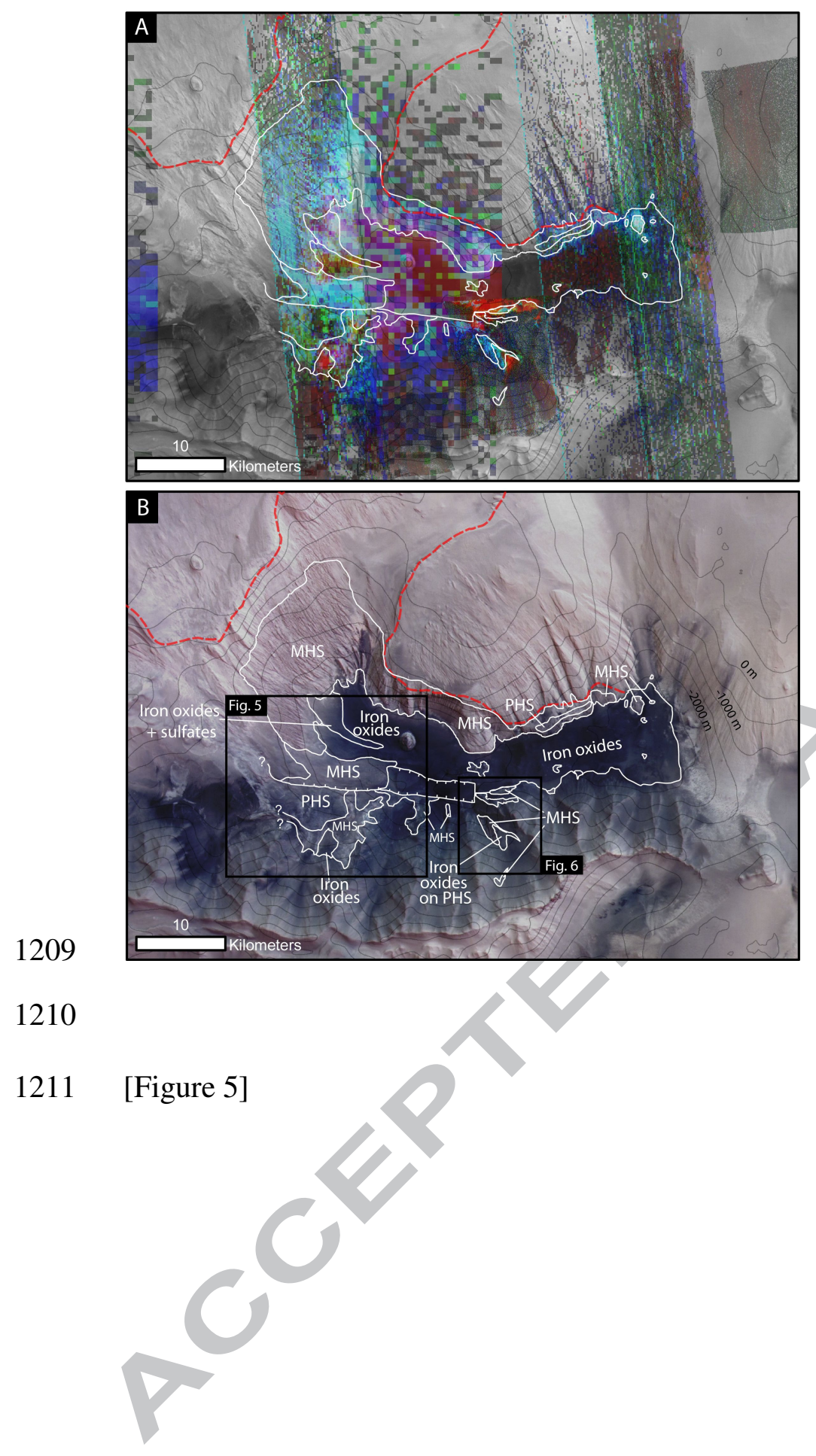



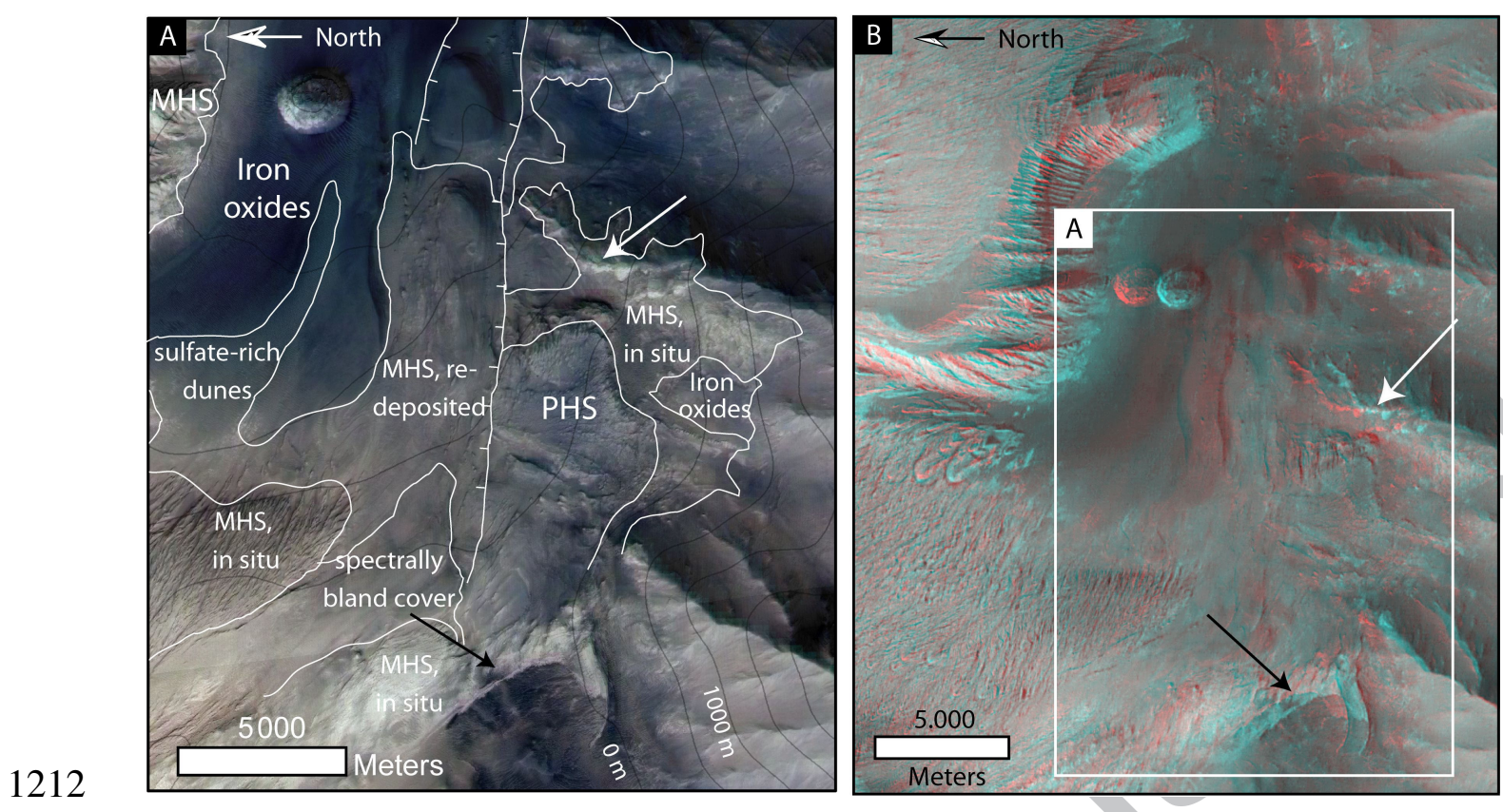

\section{3 [Figure 6]}

1214 


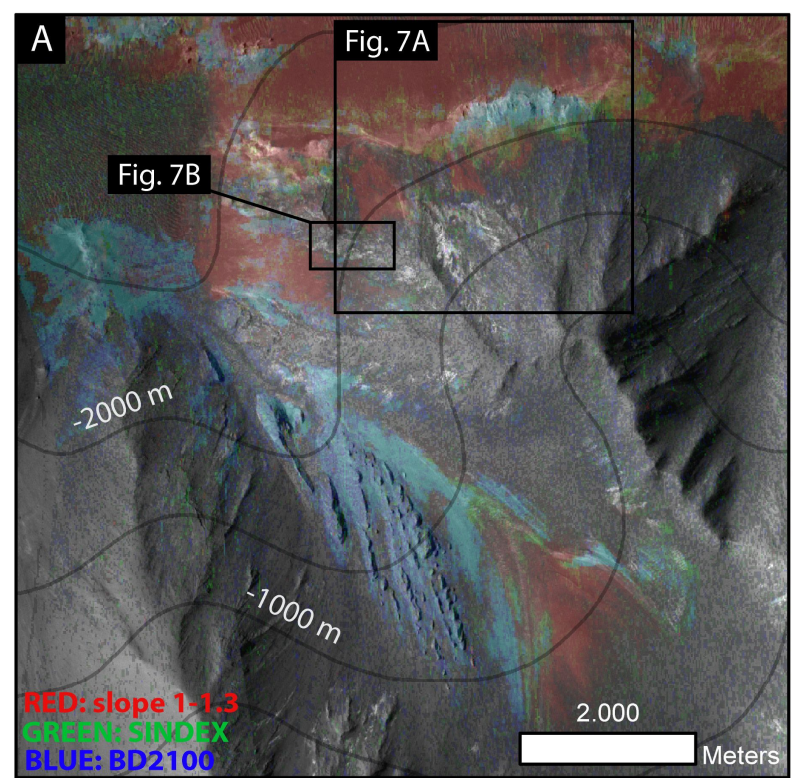

C locations of average spectra

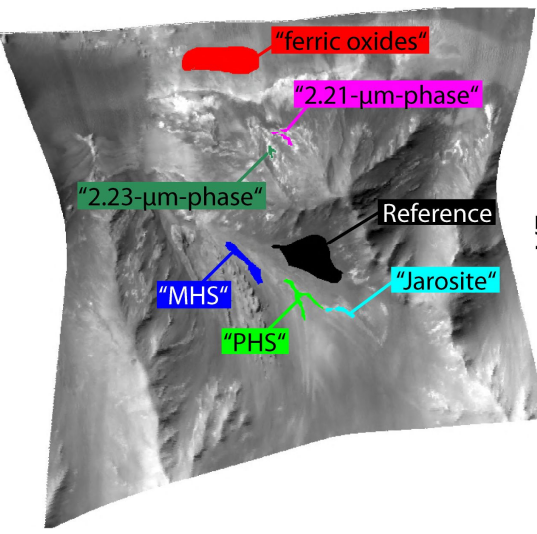

CRISM average reflectances

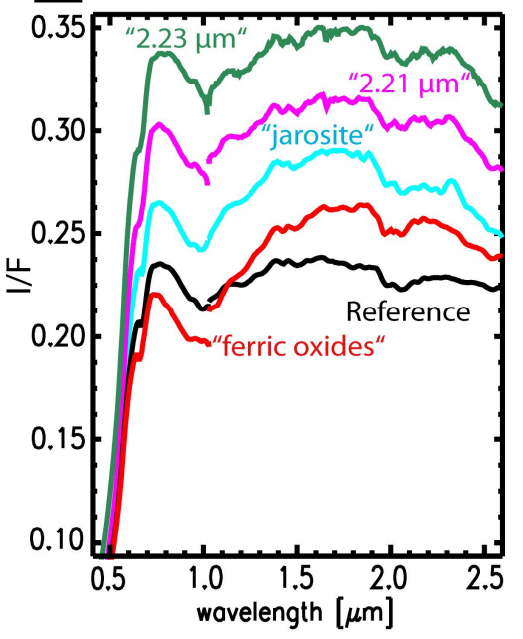

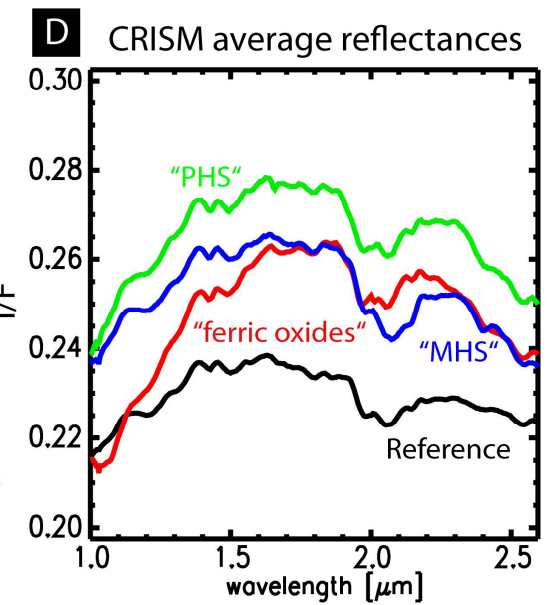

G CRISM ratioed reflectances, VNIR, continuum removed

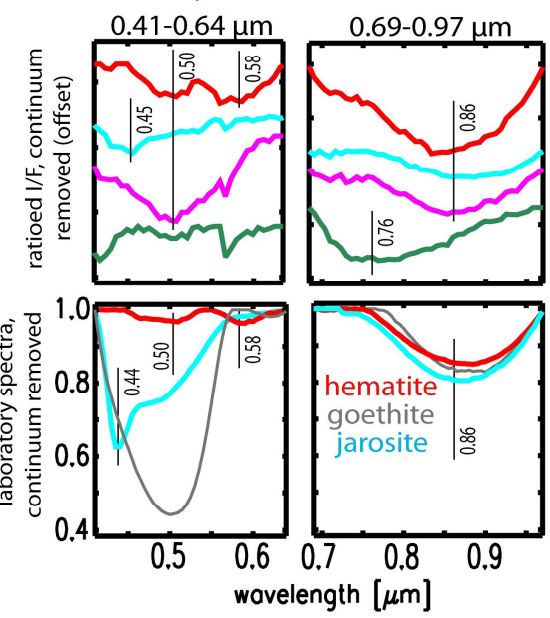

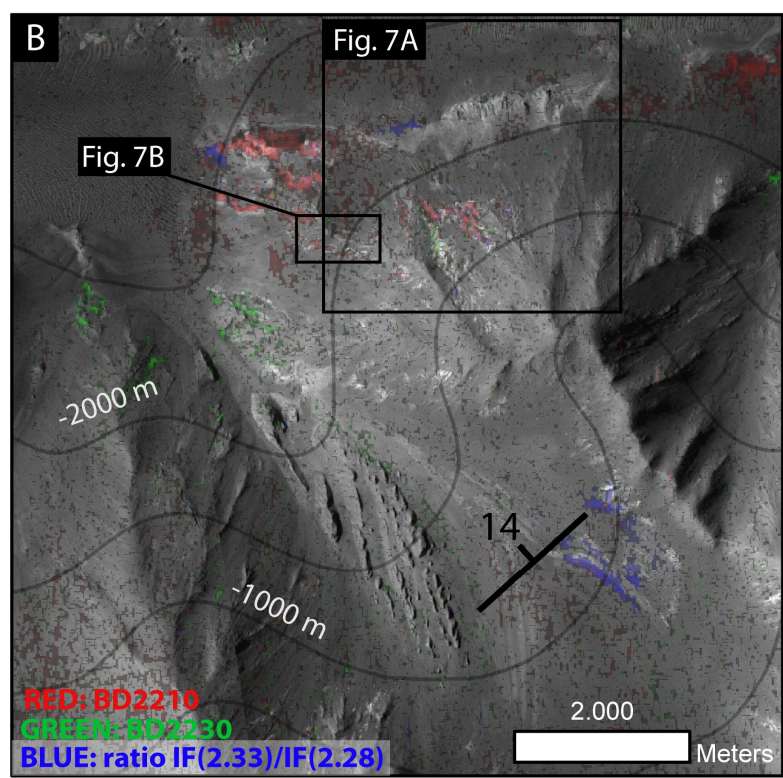

CRISM ratioed reflectances

and matching lab spectra

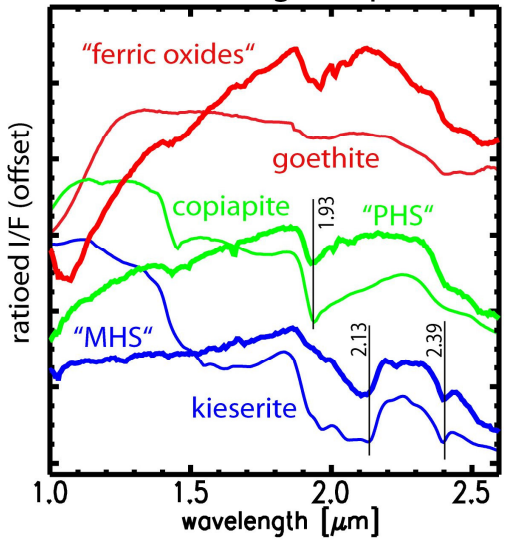

$\mathrm{H}$

CRISM ratioed reflectances and laboratory spectra

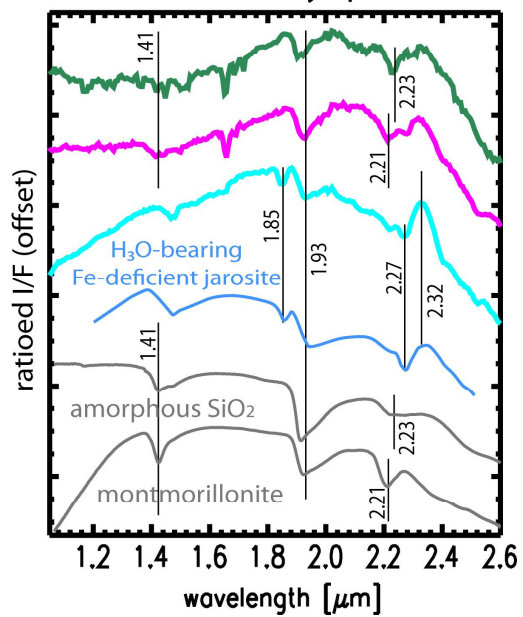




\section{7 [Figure 7]}

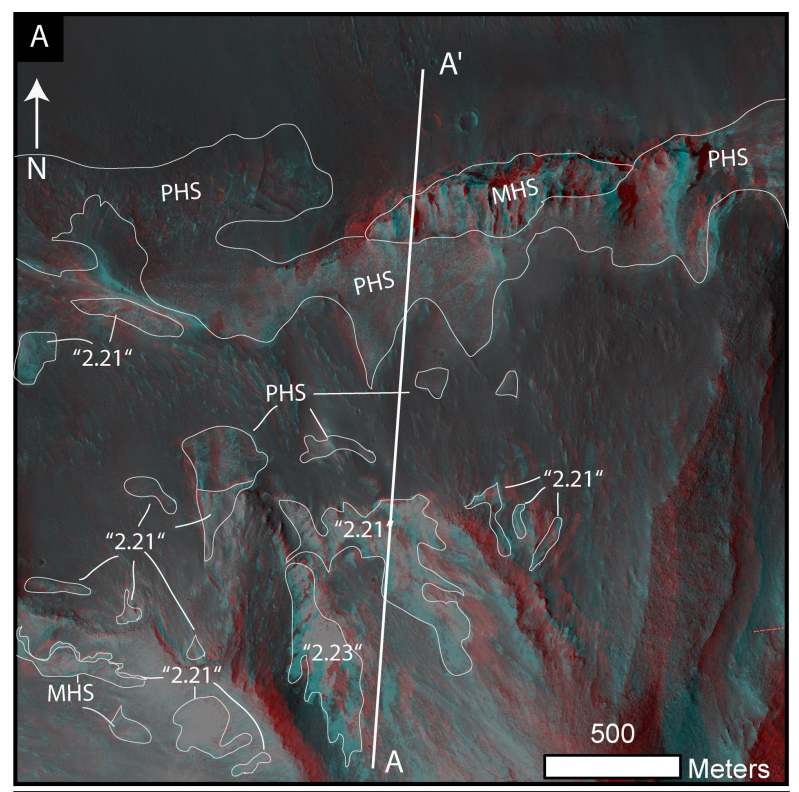

1218

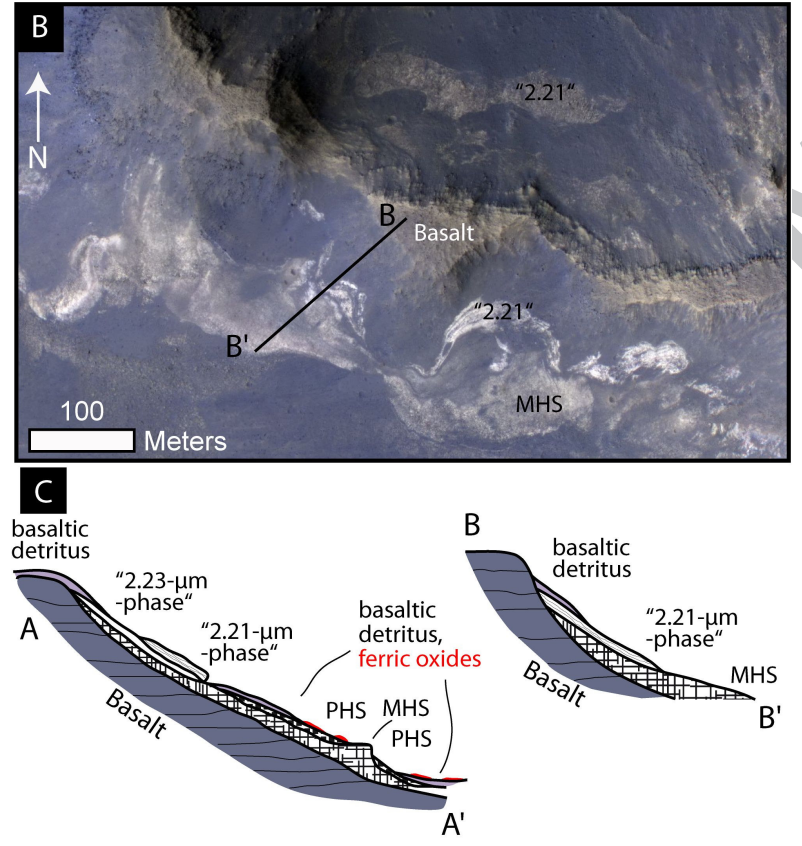

1219

$1220 \quad$ [Figure 8] 

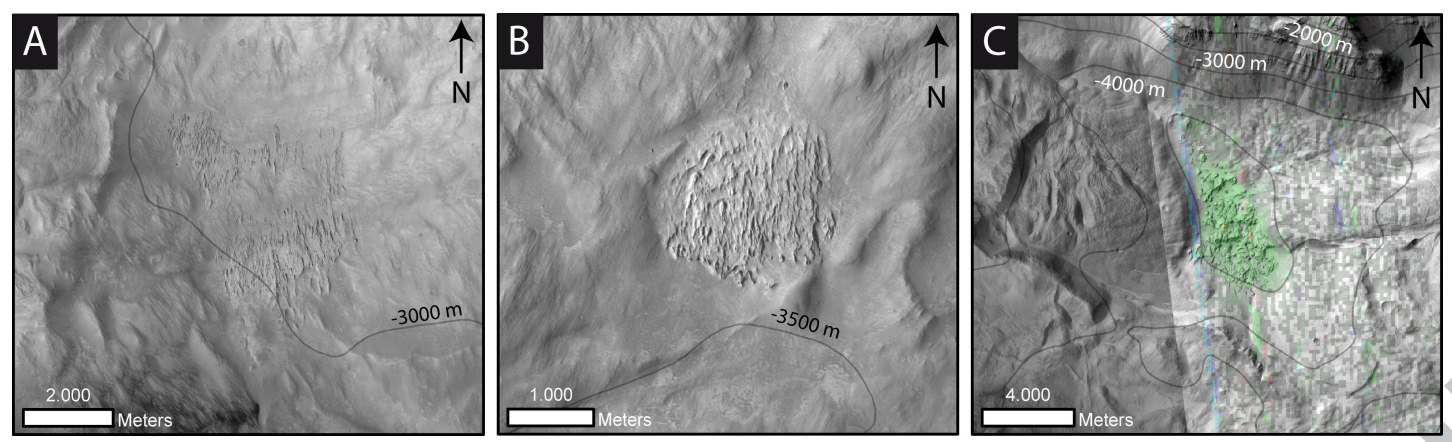

1222

\section{3 [Figure 9]}
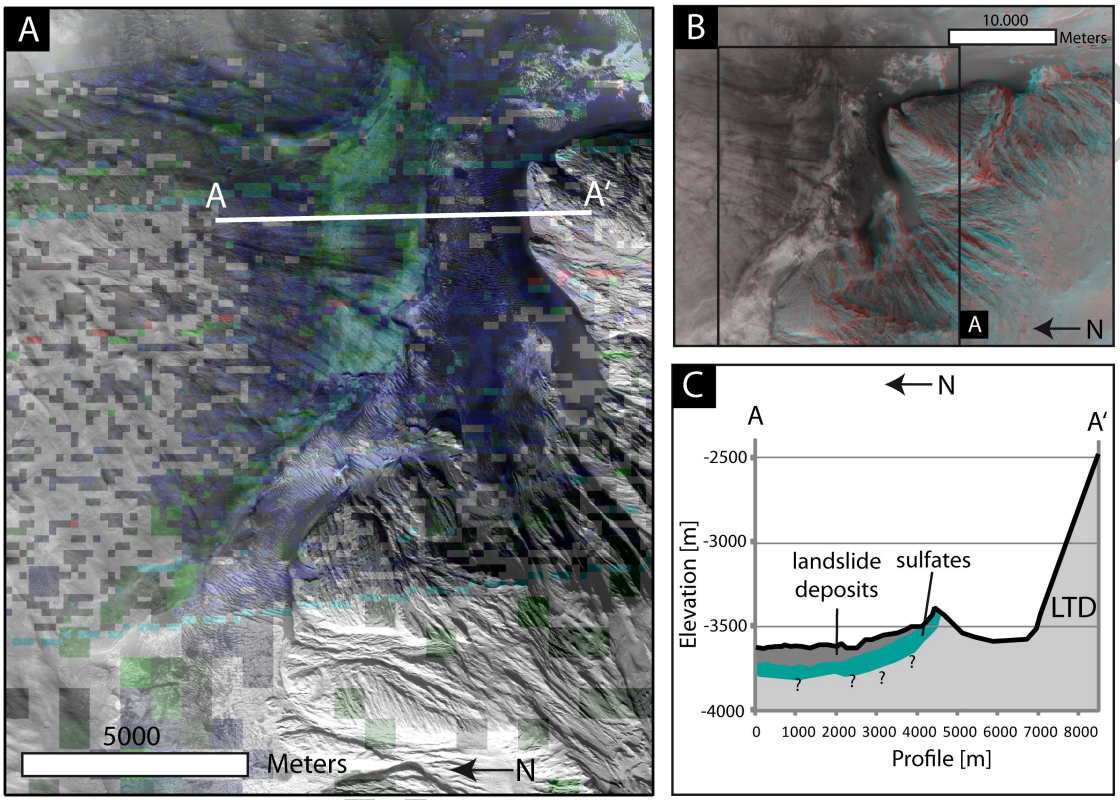

1225

1226 [Figure 10] 

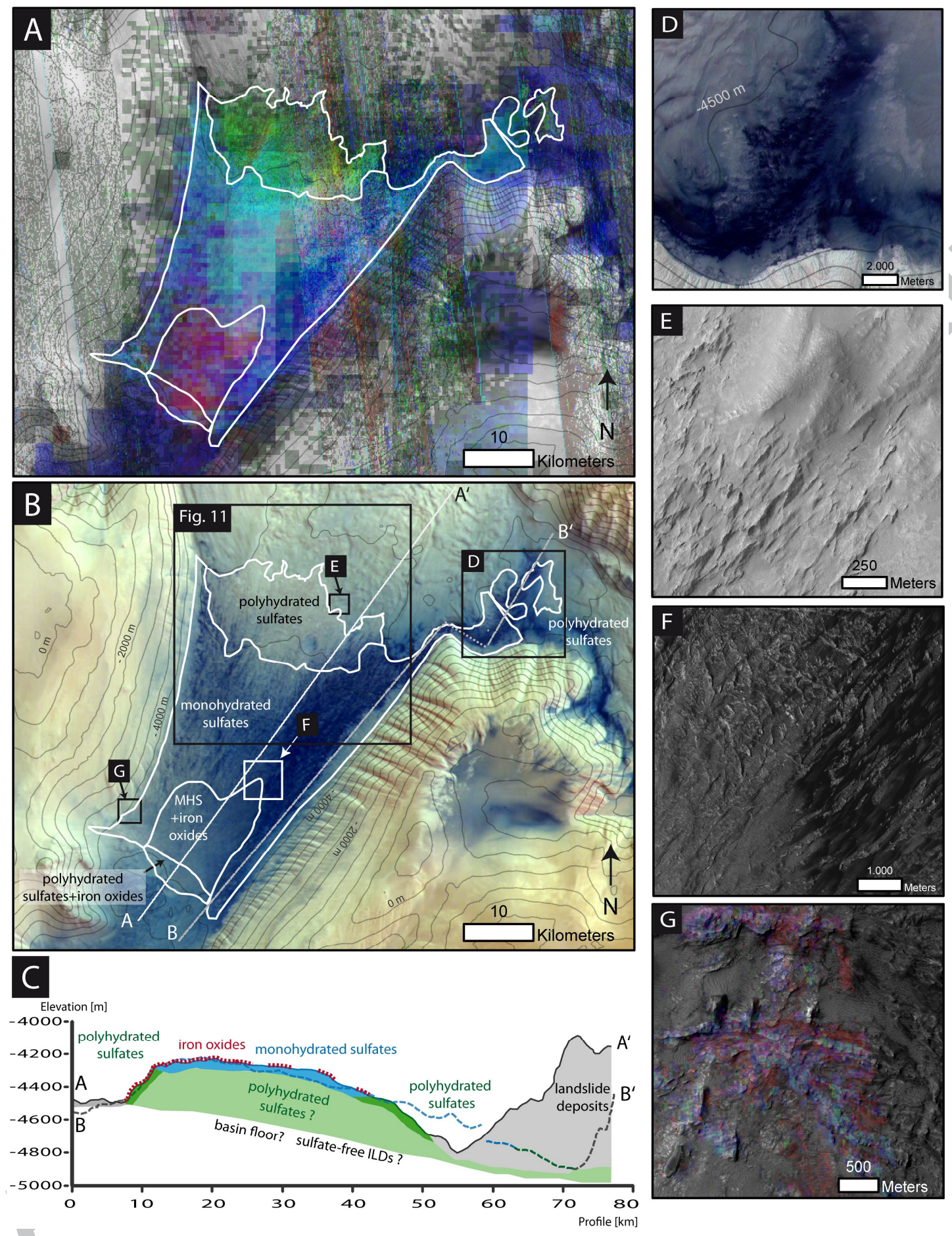

1229 [Figure 11] 

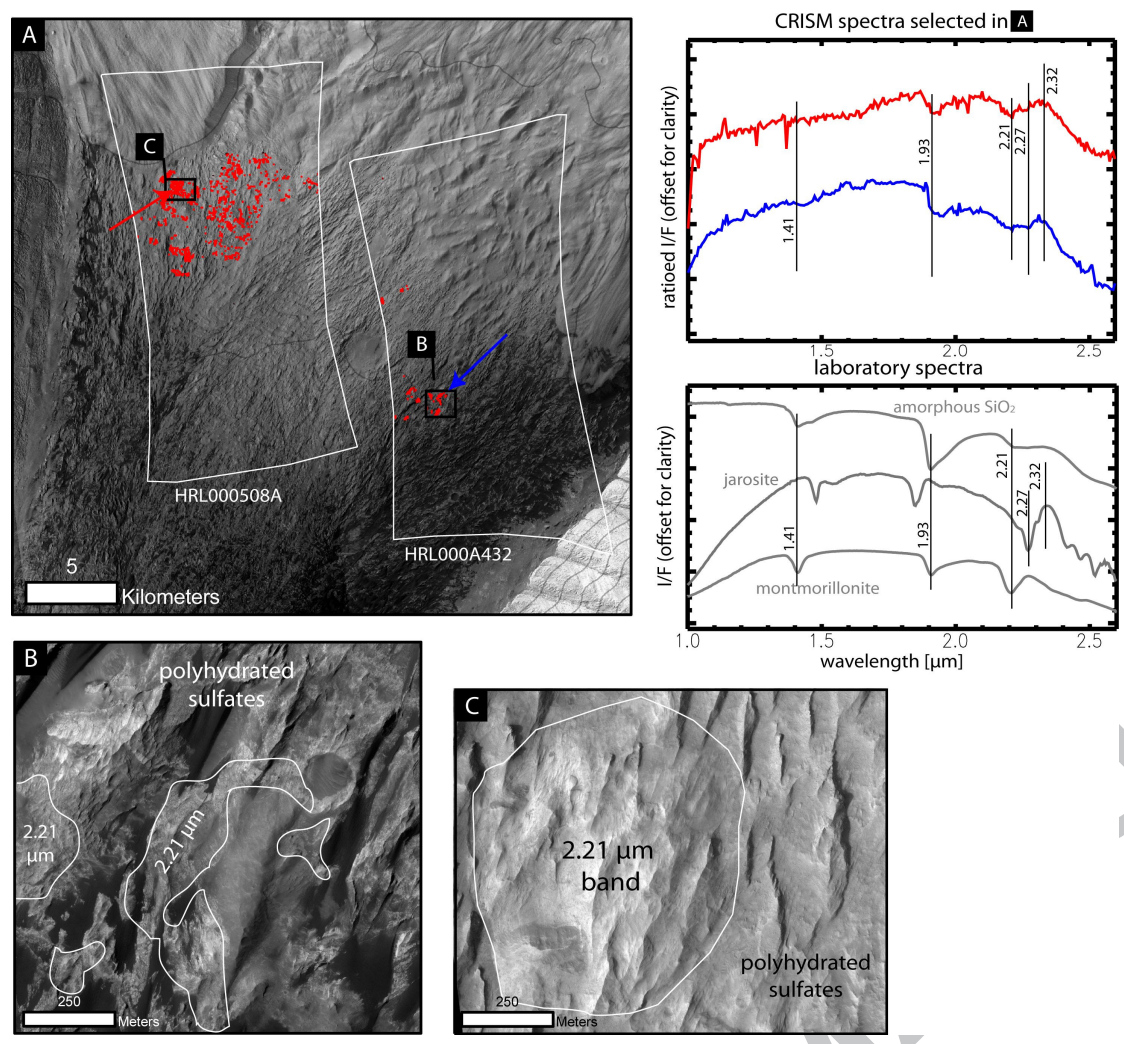

1231

1232 [Figure 12]
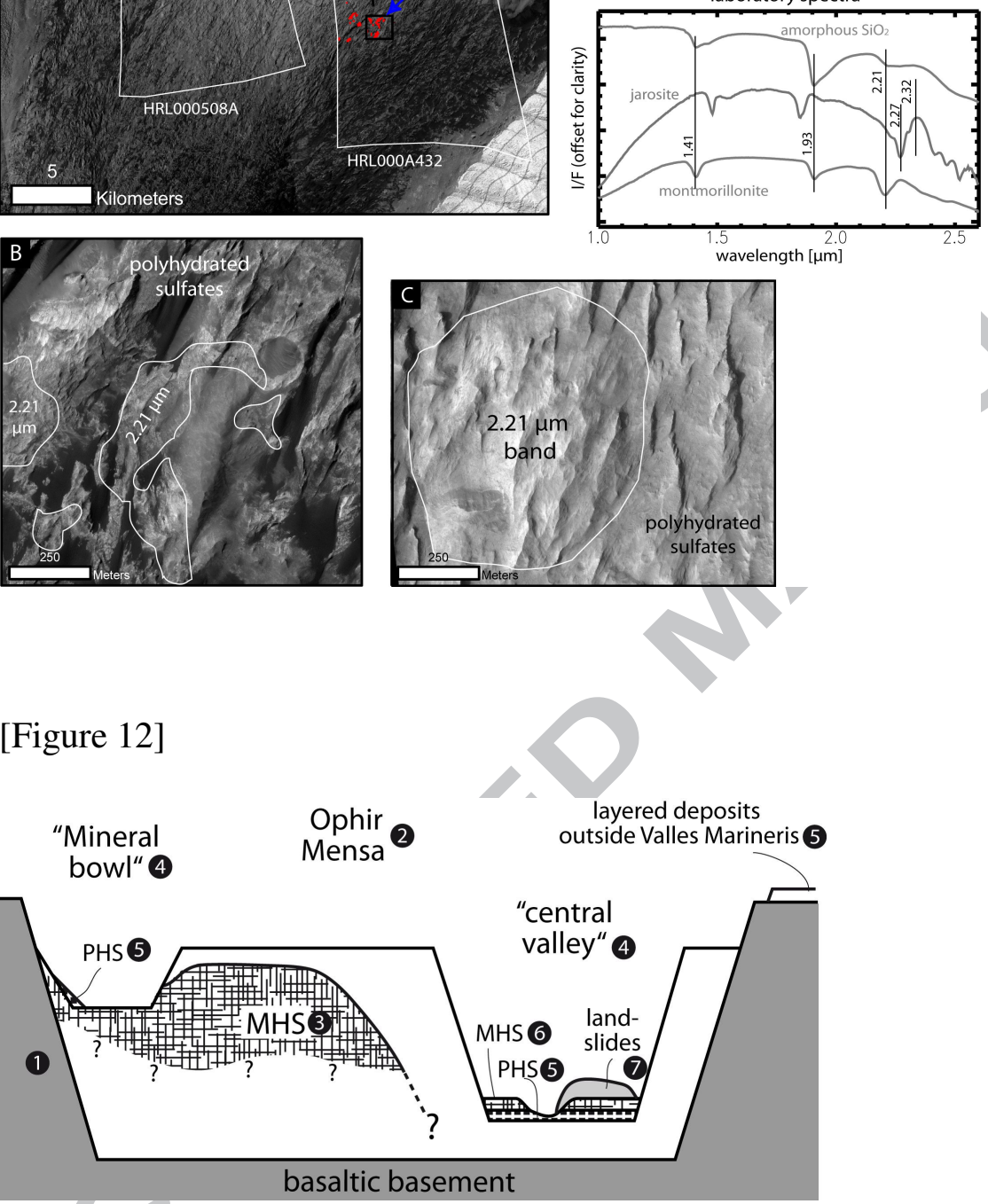

1233

basaltic basement 
Sulfates and Iron Oxides in Ophir Chasma based on OMEGA and CRISM Observations by Wendt et al.

\section{Research highlights:}

- Detection of jarosite and hydroxylated phases, kieserite, polyhydrated sulfates and hematite

- Interpretion ofmineralogy together with digital elevation models and anaglyphs

- Discussion of formation theories

-comparison to light-toned deposits elsewhere on Mars 